\title{
De las FEMINAE a LAS FEMBRES: LA MisOGINIA medieval en Cataluña y Provenza ${ }^{1}$
}

\author{
Coral Cuadrada ${ }^{2}$ \\ Universitat Rovira i Virgili
}

\begin{abstract}
Resumen
Este artículo analiza algunas de las causas del deterioro en la consideración de las mujeres desde la Alta Edad Media a la misoginia bajomedieval, en Cataluña y Provenza. Estudio: 1. La filiación matrilineal. En los actos de homenaje de los siglos X-XI los vasallos se hacen hombres o mujeres propios de su señor feudal declarándose hijos o hijas de su madre; 2. La presencia de feminae en la documentación. Estas mujeres fueron mujeres propietarias de bienes fundarios que actuaron con total libertad en compras, ventas o transmisiones, siendo las protagonistas de los negocios sin procuración o acompañamiento de ningún hombre; 3. La exaltación de la mujer en la literatura trovadoresca y el amor cortés. Al declararse la cruzada contra los cátaros se condena también esta poesía hasta prohibirla, por subversiva; y 4. La difusión del culto mariano a partir del siglo XII. Paralelamente, la normatización y elevación a la categoría de sacramento al matrimonio.
\end{abstract}

\section{Palabras clave}

Matrilinealidad, feminae, amor cortés, herejía cátara, culto mariano, sacramento del matrimonio.

\begin{abstract}
This article analyses some of the causes of the deterioration of the image of women from the Early Middle Ages to the Late Middle Ages misogyny in Catalonia and Provence. Study 1: Matrilineal affiliation. During the acts of homage of the $10^{\text {th }}$ and $11^{\text {th }}$ centuries, vassals would become men or women of their feudal lords by declaring themselves sons or daughters of their lord's Mother; Study 2 . The presence of feminae in written documentation. These women were land holding owners and were allowed to act freely in purchases, sales or transfers, playing a central role in business without any attendance or assistance from men; 3 . The exaltation of women in Troubadour literature and courtly love. With the declaration of the Crusade against the Cathars, this poetry was also censored and even banned, due to its subversive character; Study 4: The dissemination of Marian devotion from the $12^{\text {th }}$ century. Simultaneously, the standardisation and the elevation of marriage to the rank of a sacrament.
\end{abstract}

\section{Keywords}

Matrilineal, feminae, courtly love, Cathar heresy, Marian devotion, Sacramento of Matrimony.

\footnotetext{
1 El título juega con dos acepciones para señalar algunas mujeres: las feminae altomedievales, mujeres con poder económico y autoridad vs. las fembres bajomedievales, mujeres sin condición e incluso despreciables. 2 MARC (Medical Anthropology Research Center), Universitat Rovira i Virgili de Tarragona: coral.cuadrada@ urv.cat; http://www.marc.urv.cat/; https://urv.academia.edu/CoralCuadrada
} 


\section{Résumé}

Cet article traite de quelques-unes des causes de la détérioration dans la considération des femmes depuis le Haut Moyen Age jusqu'à la misogynie du Bas Moyen Age, en Catalogne et en Provence: 1. Filiation matrilinéaire. Lors des cérémonies d'hommage des Xe-XIe siècles, les vassaux, hommes et femmes, deviennent propriété de leur seigneur féodal en se déclarant fils ou filles de sa mère; 2 . Présence des feminae dans la documentation. Ces femmes étaient propriétaires de biens-fonds et intervenaient en toute liberté dans les achats, ventes ou transferts, sans devoir recourir à la procuration ou au parrainage d'un homme; 3. L'exaltation de la femme dans la littérature des troubadours et dans l'amour courtois. En même temps que l'on prêche la croisade contre les Albigeois, on condamne également cette poésie, qui est interdite, car considérée comme subversive; 4. La propagation de la dévotion mariale à partir du XIIe siècle. En parallèle, la réglementation et élévation du mariage au rang de sacrement.

\section{Mots-clés}

Matrilinéarité, feminae, amour courtois, hérésie cathare, culte marial, sacrement du mariage.

\section{Introducción}

En gozarse y quererse el uno al otro Está el amor de los verdaderos amantes. Nada puede salir bien

Si los dos no quieren lo mismo. $Y$ está loco de nacimiento El que no hace lo que ella le pide O alaba lo que no le gusta.

Por razones de interés didáctico y por convención adoptamos una periodización de la Historia que tiene sus defectos, ampliamente conocidos. De ahí la preferencia, también bastante común y muy aplicada a la Edad Media, de las transiciones. Resulta entonces que el Medievo se encuentra entre la etapa -larga, difusa- de la transición del esclavismo al feudalismo y el fin de la medievalidad que es igualmente difícil de fijar con concreción y unanimidad, aunque por comodidad la situemos a mitad o a finales del siglo XV. En la actualidad huimos de las grandes fechas, nos alejamos del 476, 1453 o 1492, pero aún así los cortes temporales muchas veces se acostumbra a marcarlos en base a hechos militares o acontecimientos culturales de relieve -renacimiento carolingio, renacimiento del siglo XII, humanismo ${ }^{3}$... Ambas soluciones, la del uso de la historia política o la de la historia cultural para dividir la Historia no nos sirve para tempora-

\footnotetext{
3 Hace muchos años Joan Kelly advertía que las mujeres no tuvieron Renacimiento, cfr Joan Kelly, “¿Tuvieron las mujeres Renacimiento?", en James Amelang y Mary Nash (eds.), Historia y género. Las mujeres en la Europa moderna y contemporánea, Institución Alfonso el Magnánimo, Valencia, 1990, p. 3-26.
} 
lizar las vivencias femeninas: seria necesario, pues, crear una periodización propia ${ }^{4}$. Las feministas, en cambio, cuando se refieren a las luchas realizadas por las mujeres, no hablan de épocas, sino de olas: el feminismo de la primera, segunda, tercera ola, aspecto que no ayuda a delimitar históricamente los avances o retrocesos de las vidas de las mujeres ni acaba de ser útil para plantearnos una periodización femenina de la Historia. Aceptamos que la posición de las mujeres declinó en la Baja Edad Media, resaltamos la misoginia ${ }^{5}$ constatable entre los siglos XIII y XV, pero no acabamos de explicarnos con total satisfacción el porqué. Es también erróneo emplear una dicotomía que anteponga una realidad femenina positiva a la Alta y Plena Edad Media y la negativa a la Baja. Hay estudiosas que opinan que la misoginia fue una constante en el arco temporal completo del Medievo, lo que implicaría matizar un rotundo antagonismo. Es cierto que desde algunas perspectivas, como es la del monacato femenino, se ha demostrado que existieron situaciones coyunturales mejores y peores también en la Alta Edad Media ${ }^{6}$. Todos estos aspectos nos llevan a reivindicar con mayor énfasis la necesidad de construcción de periodizaciones adecuadas y multifocales. Espero que mis consideraciones puedan contribuir a tal fin.

En aras a ampliar tales aseveraciones ofrezco mis reflexiones, los aspectos que voy a tratar son los siguientes:

1. La filiación matrilineal. En los actos de homenaje del Liber Feudorum Maior, conservado en el Archivo de la Corona de Aragón, los vasallos se hacen hombres o mujeres propios de su señor feudal declarándose hijos o hijas de su madre (ejemplo: ego, Guillelmum, filius Ermessenda -yo, Guillermo, hijo de Ermes-

\footnotetext{
4 Es una necesidad manifestada por varias medievalistas, $c f r$. Segura Graíño, Cristina, "Tiempo de hombres. Tiempo de mujeres", en Cristina Segura y Gloria Nielfa (eds.), Entre la marginación y el desarrollo: mujeres y hombres en la historia. Homenaje a $M^{a}$ Carmen García Nieto, Ediciones del Orto, Madrid, 1996, p. 27-42. y María-Milagros Rivera Garretas, La diferencia sexual en la historia, Publicacions de la Universitat de València, Valencia, 2005.

5 Sobre la misoginia y las cuestiones de género a nivel metodológico, cfr. Gisela Bock, "La historia de las mujeres y la historia del género: aspectos de un debate internacional", Historia Social 9, 1991, p. 55-78; y Joan Scott, "El género: una categoría útil para el análisis histórico", en AmElang y NASH (eds.), Historia $y$ género, cit. nota 3, p. 2358. Mis puntualizaciones en lo que se refiere a la historia del género y personal preferencia por la historia de las mujeres en Coral CuADRADA, "La tasca civilitzadora de les dones: les absències històriques?", en Coral CuADRADA (coord..), Memòries de dones, Arola Editors, Tarragona, 2009, p. $27-40$.

6 Jane T. Schulenburg, "Strict Active Enclosure and Its Effects on the Female Monastic Experience (ca. 5001100)", en John A. Nichols y Lillian T. Shank (eds.), Medieval Religious Women, t. I: Distant Echoes, Cistercian Publications, Kalamazoo, 1984, p. 5186; ídem, "Women's Monastic Communities, 5001100: Patterns of Expansion and Decline", en Joan Bennet et al., Sisters and Workers in the Middle Ages, The University of Chicago Press, Chicago \& London, 1989, p. 208239; ídem, Forgetful of their Sex. Female Sanctity and Society, ca. 500-1100, University of Chicago Press, Chicago \& London, 1998; Susan Stuard, "The Dominion of Gender: Women's Fortunes in the High Middle Ages", en Renata Bridenthal, Claudia Koonz y Susan Stuard (eds.), Becoming Visible. Women in European History, Houghton Mifflin, Boston, 1987², p. 153-174; Suzanne F. Wemple, Women in Frankish Society. Marriage and the Cloister, 500 to 900, University of Pennsylvania Press, Philadelphia, 1991.
} 
enda). Pero más adelante se substituirá la filiación matrilineal por la patrilineal (ejemplo: ego, Guillelmum, filius Bernardi -yo, Guillermo, hijo de Bernardo).

2. La presencia de feminae en la documentación. Estas mujeres, que se intitulan femina (ejemplo: ego, Elicsendis, femina) son mujeres propietarias de bienes fundarios que actúan con total libertad en compras, ventas o transmisiones, siendo las protagonistas de los negocios sin procuración o acompañamiento de ningún hombre.

3. La exaltación de la mujer en la literatura trovadoresca y el amor cortés. Es cierto que se trata de un amor adúltero, ya que el trovador canta a su amada, normalmente esposa de un noble. Al declararse la cruzada contra los cátaros se condena también esta poesía hasta prohibirla, a causa de considerarla subversiva, provocativa (en palabra actual: revolucionaria). Los últimos trovadores continuarán cantando a la dama, pero substituyendo a la aristócrata amante por la Virgen María.

4. La difusión del culto mariano a partir del siglo XII. La Iglesia consolida y difunde el culto a la Virgen, dando lugar así al modelo dicotómico de Eva y María (mediado por Magdalena), el cual impulsa la fuerte misoginia de las centurias posteriores. Paralelamente, normatiza y eleva a la categoría de sacramento el matrimonio.

Respecto a la dimensión espacial, una parte importante de la información manejada se refiere a Cataluña y la Provenza, por dos razones: la primera responde a los archivos trabajados; la segunda se acoge a los planteamientos temáticos planteados. No pretendo con ello que los resultados aquí conseguidos sean extensibles a cualquier otro territorio, en cada caso requeriría un estudio comparativo en profundidad a fin de detectar coincidencias y/o diferencias. El estudio conjunto de ambos territorios, en especial hasta inicios del siglo XIII, me parece justificado por motivos políticos y las innegables conexiones culturales entre estos dos ámbitos históricos.

\section{De la filiación de madre a la de padre}

Veamos como se gesta el primer indicio, el relativo a la filiación matrilineal. Años ha Pierre Bonnassie ${ }^{7}$ cuando estudió la condición de la mujer en los siglos X y XI, puso de manifiesto el hecho de que los juramentos vasalláticos a partir del siglo XI, época en la cual los escribas comienzan a anotar el origen familiar de las personas, estos llevan sólo la filiación materna, a diferencia de lo que sucedía en otros tipos de contratos. Este hecho, verdaderamente singular, es analizado por el medievalista, quien lo consideró un formulario arcaico, hipótesis que más tarde abandonará "porque antes del año 1000 las indicaciones de ascendencia son rarísimas y por otro lado los más antiguos juramentos

7 Pierre Bonnassie, Catalunya mil anys enrera: creixement econòmic i adveniment del feudalisme a Catalunya, de mitjan segle X al final del segle XI, Edicions 62, Barcelona, 1979-1981, 2 vols. 
de Cataluña y Lenguadoc no llevan la omisión de la filiación paterna típica del siglo XI". Efectivamente, el Liber Feudorum Maior ${ }^{8}$, como he señalado, está lleno de ejemplos de filiaciones por vía materna ostentados tanto por hombres como por mujeres. A veces se alternan con la masculina, pero en otros casos son las mujeres las que legalizan la herencia sin varones intermediarios.

Abilio Barbero 9 señaló que ya el conocido texto de Estrabón, en el que el autor habla de los nobles del norte de Hispania, informa que tenían costumbres parecidas a las de los galaicos, vascones y pirenaicos. Hace alusión a la preeminencia de las mujeres entre los cántabros, sociedad que denomina ginecocracia, supremacía expresada en el hecho de que las mujeres eran sujetos de derecho con preferencia a los hombres, dado de que eran ellas las que heredaban y se encargaban de casar a sus hermanos. También reclamaba atención sobre las particularidades que ofrecía la transmisión del poder político y, especialmente, la sucesión al trono en el primitivo reino astur, observando allí cambios significativos en la forma de realizar la sucesión durante la época de los primeros reyes del siglo VIII, hasta el establecimiento de la sucesión patrilineal con Ramiro I y sus descendientes, una centuria más tarde. Igualmente destacó la importancia de las relaciones matrilineales con fuerte valor político en la región pirenaica: las genealogías de los condes de Aragón conservadas en el Códice de Roda nos informan de ello.

Las noticias de Estrabón, según Barbero y Vigil ${ }^{10}$, que recogieron la matriz evolucionista de la antropología de Morgan y de la sociología histórica de Engels, indican una pervivencia del sistema de parentesco indígena hasta el período medieval. Los estudiosos señalan que en las inscripciones en las que aparecen mujeres dedicando lápidas funerarias a sus hijos e hijas no se menciona el nombre del padre de los difuntos; la mayoría de ellas son de madres a hijas e hijos y de hijos e hijas a madres, con un escaso número de dedicatorias de padres o a padres, sin filiación paterna. Y también abundan las dedicatorias de tío y tía maternos (avunculus y matertera) a sobrinos y viceversa. Tendríamos entonces dos modelos de filiación matrilineal: uno directo, representado por las inscripciones del Alto Pisuerga; y otro indirecto, en las estelas vadinenses. De acuerdo con los autores ${ }^{11}$, la idea de que la emergencia de la clase feudal en el norte hispánico habría derivado de la evolución de sociedades primitivas de organización gentilicia regidas por una filiación matrilineal, estaría respaldada por el análisis de la

\footnotetext{
8 Un ejemplo: "Yo, Bernat Guillem [conde de Cerdaña (1109-1118?)], hijo de Sança fémina, juro sobre el altar consagrado, a ti, Ramón Berenguer, conde de Barcelona, que de ahora en adelante te seré fiel, tanto de cuerpo, vida y miembros, como también del honor que tienes y después adquirirás con mi consejo, especialmente por el castillo de Besalú y todos los castillos y fortalezas de aquel condado...", Liber Feudorum Maior, CSIC, Barcelona, 1947, II, doc. 510. Mi traducción y mis cursivas.

9 Abilio Barbero de Aguilera, (1989) "Pervivencias matrilineales en la Europa medieval: El ejemplo del norte de España", en VVAA, La condición de la mujer en la Edad Media, Coloquio Hispano-Francés, Madrid: Casa de Velázquez-Universidad Complutense, p. 215-222.

10 Abilio Barbero de Aguilera, Marcelo Vigil Pascual, "La organización social de los cántabros y sus transformaciones en relación con los orígenes de la Reconquista", Hispania Antiqua, 1971, I, p. 197-232.

11 Abilio Barbero de Agullera, Marcelo Vigil Pascual, La formación del feudalismo en la Península Ibérica, Crítica, Barcelona, 1978, p. 354-404.
} 
sucesión al trono en el reino astur, donde se observa, para las primeras sucesiones, un rol destacado de las hijas de los reyes en el acceso al trono de sus maridos. Esta situación es interpretada como la última fase de un tipo de sucesión matrilineal indirecta, que constituiría un rasgo residual de la organización gentilicia originaria.

La documentación altomedieval, según Barbero ${ }^{12}$, pone de relieve el vínculo existente entre las pervivencias matrilineales y los grupos gentilicios primitivos que se habían ido transformando en comunidades de aldea, conservando la noción de una unidad de origen. Muchos investigadores de comunidades de aldea y de familia en la vieja Europa destacan también el papel fundamental de las mujeres en las comunidades analizadas: se pueden citar como muestras algunas aldeas eslavas y las sociedades familiares del País Vasco francés. Concluye, matizando la idea de filiación matrilineal de Bonnassie:

Pero la explicación de Bonnassie [una moda de las mentalidades nobiliarias que tratarían de diferenciarse así del resto de la sociedad] podría ser adecuada sólo si se tratara de una aparición en sentido estricto, aunque ahora sabemos que podría corresponder efectivamente a un uso antiguo. El hecho de que este uso antiguo se expresara por escrito en las fórmulas quiere decir que estaba tan generalizado socialmente que fue capaz de imponerse y de desplazar otros usos de la literatura jurídica.

A través de la endogamia y del incesto se fue produciendo el acceso masculino a la posesión de los bienes y a la transmisión de los derechos sobre ellos, pasando por situaciones intermedias, como la sucesión de "varón a varón, pero por línea femenina". Esta sustitución de las mujeres ${ }^{13}$ se llevó a cabo en principio dentro del mismo linaje; he aquí el porqué de la reiterada aparición en los documentos de situaciones que sin lugar a dudas pueden ser calificadas de incestuosas. Parece conveniente recurrir a Godelier ${ }^{14}$ para obtener una clara definición de las sociedades no de carácter matriarcal (que el autor considera míticas) sino matrilineales. En este tipo de organización social la filiación pasa de madres a hijas, estando las mujeres -al igual que en las sociedades patrilineales- subordinadas a los hombres "pero no a su marido o a su padre, sino a su hermano o al hermano de la madre, y se encuentran situadas bajo la autoridad de sus tíos maternos". Sin embargo, y al margen de que la tesis de la sucesión matrilineal indirecta ha sido en los últimos años objeto de serias críticas ${ }^{15}$, González Rodríguez y Santos Yanguas ${ }^{16}$, y Astarita indican que no hay informaciones que permitan defender

12 BARBERO, "Pervivencias matrilineales...", op.cit., nota 3, p. 215-222.

13 Idem, p. 216-218.

14 Maurice GodeliER, "Las relaciones hombre/mujer: el problema de la dominación masculina", Teoría, $\mathrm{n}^{\circ}$ 5, abril-junio 1980, p. 10.

15 Mar Linares García, Los lenguajes del silencio: Arqueologías de la religión, Akal, Madrid, 2012, p. 82-88.

16 Carlos Astarita, "Tesis sobre un origen gentilicio y patrimonial del feudalismo en el noroeste de España. Revisión crítica.", Anales de Historia Antigua y Medieval, 39, 2007; M. del Carmen GonzÁLez Rodríguez 
el predominio de la familia extensa y el matriarcado como elementos característicos de las sociedades del norte peninsular, considerando que el destacado rol de la mujer en el sistema de parentesco puede explicarse recurriendo a otros argumentos. Los estudios sobre la aristocracia carolingia han puesto de manifiesto que, en una sociedad donde la filiación materna era tan importante como la paterna, las posibilidades de ascensión social reposaban en gran medida en la hipergamia masculina, que permitía el acceso a la línea de antecesores de una esposa perteneciente a un grupo de parientes más poderoso ${ }^{17}$. Este esquema endogámico permitía la consolidación del patrimonio territorial. Debe agregarse, además, que proporcionaba una fuerte cohesión al grupo de parientes, fortaleciendo las solidaridades internas frente a otras parentelas. Un juego de alianzas que tiene cierta afinidad con la situación que el historiador José Enrique Ruiz-Doménec ${ }^{18}$ planteó para la aristocracia catalana, encaja igualmente el paralelismo cronológico. El autor observó que, dentro de los sectores dominantes, las relaciones de homenaje eran afianzadas mediante alianzas matrimoniales en la que los vasallos tomaban mujer dentro del grupo de filiación superior al que pertenecía su señor. Estas prácticas fueron interpretadas a la luz de la teoría de la alianza de Claude Lévi-Strauss: la reproducción de estas reglas matrimoniales a lo largo de las generaciones evidenciaría la existencia de un sistema de parentesco basado en la hipergamia masculina, en el cual los individuos tratarán de tomar esposa dentro de la familia de su madre, perpetuando las normas establecidas por sus ancestros. Así, el sistema de parentesco quedaba sustentado en la matrilinealidad indirecta, o sea que las mujeres, a partir de residuos supérstites de sus antiguos roles, cumplen ahora el papel de estrecha e involuntaria colaboración en la consolidación del nuevo modelo económico-feudal. En esta senda sus funciones fueron tan significativas que cuando se alteraban estas pautas de selección de parentesco y por ende de alianzas, se producían violentos desajustes, no sólo en el interior de los linajes, sino también en el conjunto social ${ }^{19}$. La mujer es convertida entonces en el nexo insustituible que brinda sentido a la unidad constructiva y conceptual que conocemos con el nombre de feudalismo.

Este sistema de relaciones de parentesco fue combatido con ardor por dos instituciones, que prontamente se colocaron una al servicio de la otra: Iglesia y Corona. La Corona pretendía atenuar las vigentes solidaridades propias de los lazos feudo-vasalláticos, de manera que éstas volvieran a tenerla como válida referencia. Para ello utilizó distintos medios: las peculiaridades del mundo feudal, desde dentro del cual pretendía recrear su antiguo poder; y por medio de ordenamientos jurídicos basados esencialmente en el renacido derecho romano. La estrecha colaboración de la Iglesia se dio en el plano

\footnotetext{
y Juan Santos Yanguas, "El caso de las llamadas gentilitates: revisión y propuestas", Veleia, 1987, p. 2-3; Carmelo Lisón Tolosana, Antropología de los pueblos del norte de España, Ediciones de la Universidad de Cantabria, 1991, p. 19.

17 Régine LE JAN, Famille et pouvoir dans le monde franc (VIIe - Xe siècle). Essai d'anthropologie sociale, Publications de la Sorbonne, Paris,1995, p. 226-231.

18 José Enrique Ruiz Domenec, "Système de filiation et théorie de l'alliance dans la société catalane (env. 1000-env. 1240)", Revue Historique,, 1979, p. 262.

19 José Enrique Ruzz Domenec, "Sistema de parentesco y teoría de la alianza en la sociedad catalana", en Amor, familia, sexualidad, Argot, Barcelona, 1984, p. 113-140.
} 
para el que más estaba preparada: el espiritual, que no era otro que el de las sanciones religiosas que se aplicaban a quienes no cumplieran con las disposiciones reglamentadas por los numerosos Sínodos, los que se ocuparon con especial predilección de lo relativo al parentesco y a las calidades necesarias para el matrimonio ${ }^{20}$; ello incluía una poderosa ofensiva contra lo que pudiera considerarse incestuoso y cuyo resultado final en la práctica implicaba necesariamente aflojar el entretejido de solidaridades comunitarias propias del feudalismo que se interponían entre la sociedad y la monarquía. En este sentido, Ruíz Doménec ${ }^{21}$ llama la atención sobre la presión que la Iglesia ejerció sobre la aristocracia territorial durante el s. XII, especialmente en su parte final, para que "las uniones comenzaran a realizarse según las leyes de la Iglesia".

Volviendo al papel de la mujer en la sociedad cántabra, podemos atrevernos a darle una explicación basada en condicionamientos sociales y económicos derivados en parte de la adaptación al medio. Creo muy posible que estos condicionamientos pudieron mantenerse hasta bien entrada la Edad Media y que se basaron en una economía muy primaria y de cuño pastoril, que parece perdurar mucho tiempo, hasta el punto que algunos han presentado el origen de la Reconquista como una lucha entre astures y bereberes por el control de los pastos. Quizás podamos buscar este modelo dentro del tipo de Gran Familia que, en opinión del etnólogo Mauss²2 (1971:275), es: “... [un] grupo consanguíneo que lleva el mismo nombre y viven juntos en un territorio determinado, prestan obediencia al hombre de más edad de la generación más antigua y es el hermano menor y no el hijo el que hereda...". Esta familia, denominada también grupo de filiación, puede ordenar su propia filiación por línea femenina, masculina o por ambas a la vez, es decir, cognatícia. Sin embargo, una característica generalizada consiste en que la herencia: “...se hace según la generación; la igualdad entre las gentes de cada generación es absoluta.... 23 ". Tal vez se podrían buscar algunas peculiaridades de la primitiva monarquía astur en algún tipo de linaje familiar de descendencia uterina. Sobre esto hay que recordar lo que afirma Lévy-Strauss ${ }^{24}$ sobre la descendencia matrilocal y matrilineal: "...es el hermano o el hijo mayor de la madre de familia quien tiene y ejerce la autoridad...". La familia nuclear cristiana no tiene ninguna vigencia en esta temprana época y por contra nos encontraremos con la Gran Familia en la que todos los varones actúan y se comportan como hermanos: “...nosotros distinguimos bien entre hermanos y primos. Pero en las sociedades que observan el parentesco clasificatorio yo llamo hermano a todos los hombres de la misma familia... ${ }^{25}$ ".

El establecimiento de un sistema de sucesión de padres a hijos debió convivir con las transformaciones de la sociedad montañosa. En realidad éste no es un fenómeno ligado

20 Anita Guerreau-Jalabert, "Sobre las estructuras del parentesco en la Europa medieval", en Amor, familia, sexualidad, Argot, Barcelona,1984, p. 55-67.

21 Ruiz Domenec, "Sistema de parentesco...", op.cit., nota 12, p. 235.

22 Marcel Mauss, Introducción a la Etnografía, Istmo, Madrid, 1971, p. 275.

23 Robin Fox, Sistemas de Parentesco y Matrimonio, Alianza, Madrid, 1985, p. 42-43.

24 Claude Lévy-Strauss, Las Estructuras Elementales del Parentesco, Paidós, Barcelona, 1993, I, p. 160.

25 Mauss, Introducción ..., op.cit., nota 15, p. 262. 
exclusivamente a esta zona geográfica, sino que abarca todo el norte de la península, incluido el Pirineo o parte del mismo. Quizás si tuvieron economías pastoriles semejantes, pudieron tener igualmente relaciones sociales y sistemas de jefatura similares. El proceso de cristianización y el desarrollo de una economía agrícola junto con las transformaciones familiares que implicaban el grupo familiar conyugal-cristiano no fueron procesos automáticos y sincrónicos en todo el territorio. Los grupos marginales, aquellos que estaban más unidos a la ganadería trashumante, debieron mostrar una mayor resistencia a la pérdida de sus tradiciones que bien pudo ser considerado por los habitantes más cristianizados y sedentarizados de los valles como una resistencia a la cristianización. Fueron considerados o asimilados al paganismo y de una inicial suspicacia se pasó a una desconfianza total que concluyó en su discriminación.

No es sólo en Cataluña o en el norte peninsular donde encontramos reminiscencias arcaicas. Los textos de los romances viejos y las tradiciones locales a las que hacen referencia muestran un tejido de relaciones interpersonales que revelan estructuras familiares y sociales muy añejas, de tipo clánico uxorilocal, donde la filiación matrilineal y la cognación se complementan ${ }^{26}$. Es necesario remarcar que ya en la segunda mitad del s. XIII las estructuras familiares de tendencia horizontal habían sido substituidas en los estratos dominantes de la sociedad castellana por una organización familiar agnática, o sea vertical, fundamentada en un estricto principio patrilineal que negaba a las mujeres toda legitimidad en el ejercicio de la autoridad familiar y les cortaba cada vez más el acceso al poder decisorio sobre el patrimonio. Una tendencia que comienza a afirmarse en la península ibérica a lo largo del s. XII y se encuentra bien consolidada hacia la mitad del XIII. Otros estudios sobre la organización del espacio y la sociedad en la comarca de Lara en la Alta Edad Media ${ }^{27}$ remarcan que, en el curso de los siglos X y XI estaban aún en uso, aunque ya con signos de degradación, estructuras de parentesco antiguas, de tendencia matrilineal, las cuales hacían a las mujeres las detentadoras efectivas del territorio y las figuras dominantes del grupo cognático, aspecto que encuentra su eco en otros territorios peninsulares ${ }^{28}$. Volveré sobre estas cuestiones más adelante, cuando trate el tema del matrimonio. Se produce un cambio, pues, en el sistema familiar desde el siglo XI, pero se mantiene en el Pirineo el papel relevante de la madre en la familia, ya que los hombres de todas las clases sociales serán identificados por su nombre de pila seguido de "hijo de..." y el nombre de la madre. Esto perdurará, en algunos valles pirenaicos y del pre-Pirineo, hasta bien entrado el s. XX.

\footnotetext{
26 Julio Escalona Monge, "Épica, crónicas y genealogías en torno a la historicidad de la leyenda de los Infantes de Lara", Cahiers de Linguistique Hispanique Médiévale, no 23, 2000, p. 135-147.

27 Julio Escalona Monge, Transformaciones sociales y organización del espacio en el alfoz de Lara en la Alta Edad Media, Universidad Complutense de Madrid, Madrid, 2001.

28 Marcelo Vigil PASCUAL, "Romanización y permanencia de estructuras sociales indígenas en la España septentrional" en Alberto M. Prieto Arciniega (coord.), Conflictos y estructuras sociales en la Hispania Antigua, Akal, Madrid, 1977, p. 129-137; Barbero, Vigil Pascual, La formación ..., op.cit, nota 5; Manuel Salinas de Frias, La organización tribal de los vettones, Universidad de Salamanca, Salamanca, 1982.
} 


\section{De las feminae a las dominae y a las pubilles}

El segundo indicio se basa en la presencia de feminae en la documentación. En los siglos IX y X continuaba vigente en Cataluña, como lo demuestran numerosos documentos, el derecho visigótico romanizado, compilado en latín en el Liber iudicum, o Libro de los jueces, en época del rey Sisenando, y en vigor desde el año 634, con adiciones sucesivas. Más de trescientos años después de su promulgación, aquel derecho, que había sido el más explícito y detallado, en lo que se refiere a la familia, de todos los derechos germánicos, continuaba siendo utilizado habitualmente por los jueces catalanes en los juicios públicos y se le citaba explícitamente. De los doce libros del Liber, por lo menos tres (el segundo, el tercero y el cuarto) contienen elementos esenciales para comprender la situación de la familia catalana en el período de los siglos VII al $\mathrm{X}$, que no habría cambiado esencialmente, no obstante el paso y la influencia de los musulmanes y los carolingios. Se puede ver que en este derecho, si bien no se equipara totalmente la mujer al hombre, ya que ella no puede ser procuradora de otro, sólo de ella misma, en cambio la niña, desde los catorce años, puede hacer de testigo en los juicios, heredar igual que sus hermanos los bienes del padre, de la madre, de los abuelos y de los hermanos, y a la vez dejarles bienes en herencia y repartirlos entre los parientes. Puede comprar y vender, casar y dotar hijos e hijas. Cuando entra en matrimonio puede recibir del marido, sea virgen o viuda, la décima parte de los bienes de éste (diezmo conyugal), en concepto de arras, hasta la suma de 1.000 sueldos. La donación propter nuptias la tomará en concepto de dote o esponsalicio desde el compromiso. Igualmente, los conyugues pueden hacerse donaciones entre sí. Pero si la mujer vuelve a casarse antes del año de la muerte del marido pierde la mitad de los bienes, en beneficio de los hijos o parientes.

Los niños, desde los diez años, pueden ordenar sus bienes. Con dos años más prestan juramento de fidelidad a la autoridad superior. El compromiso, con la entrega de las arras y el anillo, y sellado con un beso, no puede alargarse más de dos años ni romperse. Los hijos y las hijas heredan conjuntamente y, si se reparten la herencia, han de pagar entre todos el juez y el sayo. No existen aún ni el hereu, ni la pubilla, que veremos más adelante. Todos los hijos vivos de ambos sexos heredan la parte que les corresponde, y los hermanos solteros (bacallars o cabalers) suelen quedarse a vivir en la casa paterna y colaboran en la explotación agropecuaria familiar. No se discutía la posibilidad de las mujeres de poseer bienes propios y, al contrario, abundan las referencias de mujeres propietarias. Estas mujeres podían vender o donar a terceros, solas, acompañadas por los hijos, o con el consentimiento de parientes o parientas. Los bienes inmuebles los heredan no sólo los hijos, sino también las hijas con plenos derechos. Hay muchos documentos, pues, de esta época, preferentemente los relativos a las transacciones económicas y de carácter patrimonial, en los cuales la protagonista del negocio jurídico es una mujer que se intitula femina. Son escrituras que han sido analizadas por los especialistas desde el punto de vista de la historia económica, sin entrar en las causas que permiten a estas mujeres actuar con tanta independencia. Aún ha habido menos interés en saber el 
porqué de su título. Hace años, constaté su existencia en el Maresme altomedieval: las encontré pero tan sólo cité su presencia. Más tarde desaparecen de la documentación, aunque a partir del Doscientos aparece otra denominación para algunas mujeres de la Cataluña Vieja: domina; y, un siglo más tarde: domina et propietaria.

Después de largo tiempo de reflexión y de lecturas llego a la conclusión de que estas feminae, ricas mujeres campesinas, gozaban de un estatus especial, fueran casadas o viudas. Es la muestra en el mundo rural catalán de lo que Duby ${ }^{29}$ captó en la aristocracia francesa anterior al s. XII. Dijo:

Surge la necesidad de distinguir entre la res publica y la res familiaris, entre dentro y fuera de la casa, entre el público y el privado. Según el modelo que proponían los prelados del siglo IX, cuando describían la perfecta ordenación del palacio carolingio, la dama es la responsable de la 'economía', su misión es la de mantener en orden la casa.

En Cataluña las costumbres son muy similares. En consecuencia, es tarea de la mujer atender a las cuestiones inherentes al patrimonio. Según el glosario Du Cange ${ }^{30}$ una de las acepciones de femina, según la Capitular 6 del año 803, es la que posee un feudo adquirido antes de las nupcias, o por derecho hereditario obtenido después de la boda: ea quce feudum possidet ante nuptias acquisitum, vel quod hoereditario jure post nuptias ei obvenit. Lo cual nos indica que estas mujeres eran propietarias y de elevado rango social. Veamos algunos ejemplos de ellas.

Se habla, en el 892, de una vinea de Emiliana, femina, vel de suos heredes. Los hermanos podrán heredar y poseer conjuntamente los bienes cedidos en alodio, y cada uno dispondrá de la venta de la parte de los bienes que hereda a voluntad. Aparecen también Recosinda femina (año 922); terra Alonis femine et heredum suorum (año 922); terra de Quintilio femina (año 928). Más tardías son las relativas al Maresme ${ }^{31}$. El 13 de abril de 1087, Ricarda, femina, vende un alodio a Dalmau Bernat y esposa Adaleis, hija suya,

29 Georges DuBy, Damas del siglo XII. 2. El recuerdo de las abuelas, Alianza Editorial, Madrid, 1998, p. 182.

30 Du CANGe et al., Glossarium medice et infimce latinitatis. Favre, Niort, 1883-1887. t. 3, p. 430, col. b. Disponible en: http://ducange.enc.sorbonne.fr/?clear=1 [consultada 25.08.14].

31 Coral Cundrada, "Documentació Medieval", Fulls del Museu Arxiu de Santa Maria, n” 30, p. 46-50, y $n^{\circ} 31$, p. 36-40. Otros ejemplos de feminae: donación de Saborosa al monasterio de San Cugat (964); testamento de Mello (1002); acto de reparación a Beliarda (1008); Venta realizada por Altemir y Síndola (1017); Venta de Adaleit a Beliarda (1058); juicio en el que Bonfill Guillem y Sicarda denuncian a Llobet Llobató (1066); ordalía aplicada a Bonadona (1081). En: Cartulari de Sant Cugat, CSIC, Barcelona, 19451981, doc. 73; ídem, II, p. 377; Manuel RovirA, "Notes documentals sobre alguns efectes de la presa de Barcelona per al-Mansur (985)", Acta/Mediaevalia, no 1, 1980, p. 50-53; Archivo de la Catedral de Barcelona (ACB), Liber Antiquitatum, I, doc. 2; Jesús Alturo, L'arxiu antic de Santa Anna de Barcelona del 942 al 1200, Fundació Noguera, Barcelona, 1985, doc. 71; José Rius SERrA, El derecho visigodo en Cataluña, Sant Cugat, 1964, II, p. 832-833; Cebrià BARAut, "Els documents, dels anys 1076-1092, de 1'arxiu capitular de la Seu d'Urgell', Urgellia, 7, 1984-1985, doc. 947. 
y Berenguer Bernat. Esta propiedad, como ella misma indica, no la posee de herencia de su marido, sino que formaba parte del patrimonio de su linaje, ya que le ha llegado de su hermano, Miró Guadall. Un alodio que había retenido en dominio cuando dio a Dalmau su hija, ahora se lo vende por cien mancusos de oro de Valencia, y según este pacto: Ricarda disfrutará del usufructo mientras viva y se lo legará a su muerte para que él haga lo que quiera, con todo el dominio y potestad. En 1136 Ermesenda, femina, y sus cuatro hijos, establecen a Ramón Berenguer en un alodio con manso, campos, tierras cultas y yermas, juntamente con otro alodio y bailía de Vilasar, aclarando que si éste no tuviera infante legítimo ha de legar el patrimonio a uno de sus hermanos, y que habrá de pasar siempre de uno a otro de su parentela.

La historiografía europea tradicional sobre familias urbanas medievales no distingue, por lo que a la organización familiar se refiere, entre un modelo urbano y el modelo de la nobleza rural. Según esta visión, existe una reforma de las estructuras de los parentescos y de las instituciones domésticas a partir del siglo XI, cuando se pasa de un sistema familiar en el cual predominan las relaciones cognaticias a uno de afiliación agnaticia -como hemos visto más arriba- en el que la línea de descendencia corresponde, bien a todos los varones, que explotan colectivamente los bienes heredados (tierras, cargos, castillos), bien a un solo heredero, quien asegura la representación única de la familia y del linaje en cada generación. Una razón de este cambio se encuentra en la reforma gregoriana impulsada por la Iglesia, que otorga carácter indisoluble al matrimonio, poniendo en relieve la familia nuclear, definiendo y prohibiendo el incesto entre consanguíneos y legitimando la paternidad y la condición del heredero. Otro motivo del cambio es la necesidad de no dividir el patrimonio rural de los señores porque ahora es de allí de donde extraen sus rentas principales, dado que las huestes y cabalgadas han dejado de ser fuentes apreciables de riqueza. Sin embargo, es necesario saber si este modelo familiar nobiliario, originario del mundo campesino y que se inserta en la sociedad europea, se adecúa también en los espacios urbanos. Tomo como ejemplo Barcelona. En la ciudad (y en su entorno rural colindante), no parece producirse la misma reforma de parentesco que acabo de describir, porque se mantiene la conciencia de divisiones amplias entre los familiares maternos y paternos y las respectivas competencias o influencias que estos parentescos ejercen sobre la nueva familia nuclear conyugal compuesta por el matrimonio y los hijos. No en vano, muchos documentos notariales de compraventa de principios del s. XIII establecen la identidad de las partes con referencia, no sólo al padre, sino también a la madre. La misma noción de familia o de casa alude en esta época a un conjunto de personas indefinidas (parentela) ligadas por vínculos de sangre que forman grupos numerosos y confusos de parientes.

Bensch $^{32}$ ha examinado 263 testamentos de personas laicas de Barcelona entre $1100 \mathrm{i}$ 1290. Constata que la práctica testamentaria durante este período se aparta considerablemente de las previsiones legales contenidas en el Liber iudiciorum visigodo. Entre 1100 y 1140 la estrategia de los testadores era conservar las propiedades familiares unidas

32 Stephen P. BEnsch, Barcelona i els seus dirigents 1096-1291, Proa, Barcelona, 2000. 
con herencias conjuntas e indivisibles, por lo tanto se rechazaba la división igualitaria del patrimonio, promovida por el Liber, aunque se respetara el principio igualitario de establecer las cuotas indivisas. Hacia el 1200, cuando el monarca ofrecía la posibilidad de efectuar inversiones lucrativas en sus finanzas, los patricios barceloneses tendieron a concentrar sus recursos familiares más valiosos en manos de un solo heredero, a fin de facilitar estas beneficiosas inversiones para la familia. Con todo, la propiedad conjunta e indivisible no se extinguió, sino que coexistía con la figura del hereu, que irá convirtiéndose en mayoritaria a partir del primer hereu testamentario fechado, en 1227. El cambio de sistema de los ciudadanos acomodados de Barcelona no obedece a una reacción defensiva, como la de los nobles europeos, porque su potestad patriarcal y sus facultades económicas estarán moderadas por los derechos de los hermanos y hermanas legitimarios y por la posición que ocupan las esposas y viudas en el ámbito patrimonial familiar.

Lo que ahora me interesa es presentar una posible evolución de la figura de la femina altomedieval. Hemos constatado su existencia aún en 1136, más tarde desaparecen de la documentación, pero a finales del s. XII (1192) encuentro que, a partir de la capacidad contractual de la mujer para alienar o disponer mortis causa de la dote marital o esponsalicio, muchas viudas de Barcelona se convierten en majores i senyores (mayores y señoras), domina et potens, lo que indica una cierta gestión del fondo conyugal y, por lo tanto, del patrimonio del marido. En el s. XIII aparece la domina, y en el XIV la titulada domina et propietaria. El derecho civil catalán ofrece prácticas singularísimas de transmisión de herencia y del rol femenino en ella, materializadas en la institución del hereu (vigente desde el s. XIII al XX), la cual regula la transmisión de la propiedad mediante el heredamiento a los hijos e hijas. La institución del hereu a través de heredamiento (heretament) es, pues, y ante todo, una forma de transmitir la herencia. Los padres ceden lo esencial de su patrimonio a un único hijo o hija, normalmente en ocasión de sus esponsales. Es, por lo tanto, una fórmula hereditaria que conlleva la transmisión indivisa de los patrimonios y es desde este punto de vista que ha sido descrita y analizada por juristas e historiadores del derecho ${ }^{33}$. Sin embargo, dicha institución tiene otra característica importante: la transmisión de derechos se produce formalmente antes de la muerte de los padres, pero con una reserva de usufructo vitalicio.

Por consiguiente, los padres y el hereu, junto con su esposa, deben compartir y convivir en el mismo patrimonio familiar, según unas reglas preestablecidas. La residencia patrilocal del hereu tiene como resultado la tendencia a formar familias de tipo troncal. La sucesión patrilocal de distintas generaciones de hereus conduce a un alto grado de identificación de la familia con la casa en la que viven, aspecto que ha sido analizado por

33 Guillem M. DE BrocÀ, Historia del Derecho de Cataluña especialmente del Civil y exposición de las Instituciones del Derecho Civil del mismo territorio en relación con el Código Civil de España y la Jurisprudencia, Generalitat de Catalunya-Departament de Justícia, Barcelona, 1985 reed [1918], p. 699-741; Jesús Lalinde Abadía, "La problemática histórica del heredamiento", Anuario de Historia del Derecho Español. Tomo XXXI, 1961, p. 195-228; Jesús Lalinde Abadía, El Derecho sucesorio en el "ReCognoverunt proceRES", Barcelona, 1963, p. 133-248. 
antropólogos y sociólogos a partir de la observación de sociedades contemporáneas ${ }^{34}$. El caso de Cataluña es parcialmente compartido con las comarcas aragonesas colindantes por el noroeste. En el resto del Pirineo aragonés y navarro, en el País Vasco, en ciertas regiones gallegas y en áreas dispersas de la cornisa cantábrica, se dan variantes de unigenitura, con tendencia en mayor o menor grado discernible hacia la primogenitura. Por lo demás, en las regiones citadas en segundo lugar, el elegido como sucesor suele ser simplemente mejorado, es decir, recibe una parte adicional de la herencia paterna respecto al resto de sus hermanos, mientras que en Cataluña lo habitual es que el hereu sea nombrado heredero universal, haciéndose cargo del patrimonio familiar inmueble en su integridad. De lo que se conoce por la literatura, existen o han existido prácticas de heredamiento indiviso en las Islas Británicas y gran parte de Irlanda, los países nórdicos, la mayor parte de Alemania, a excepción de la cuenca alta y media del Rhin y la región de Turingia; en Austria, la Bretaña y el mediodía francés, y ciertas comarcas alpinas italianas y suizas ${ }^{35}$.

Si el hereu tiene hermanos, estos deben casarse fuera o permanecer solteros en el hogar paterno y así las familias troncales pueden ser muy numerosas y, a la vez, propiciar la emigración de una parte más o menos importante de sus miembros, los hijos segundones (fadristerns) o las hijas, según el contexto demográfico y las expectativas económicas de la comunidad doméstica. Estas dos características: transmisión unigénita del patrimonio y familia troncal son las que dan sentido a la institución de hereu tal como se ha venido utilizándose hasta fechas muy recientes en una gran parte de la Cataluña rural. $\mathrm{To}^{36}$ recogió algunos ejemplos de institución de hereu entre 1061 e inicios del s. XIII, ubicados en casi todo el nordeste catalán. Se trata en su mayoría de donaciones efectuadas por los padres a favor de un hijo, sobrino o hija.

El caso más antiguo es de 1061 y se efectúa a favor de una hija: Dolça recibe de sus padres Guillem de Cellers y Bonadona un honor en las laderas del Montseny, condado de Osona. No tenía hermanos varones, sólo una hermana llamada Guillema. Y Flandina, otra hija instituida pubilla en 1180, sólo tenía otra hermana. Es frecuente encontrar alusiones a heredamientos también en los pactos matrimoniales, así, por citar un ejemplo que nos interesa particularmente por el título por el que se la nombra, en los esponsales de Ramón y Arsenda, en 1157, aparece el consentimiento de la madre de Ramón, que le cedió el manso y será, mientras viva, domina et potens. Los heredamientos más antiguos y las primeras evidencias de las familias troncales no corresponden, como se ha interpretado desde alguna perspectiva historiográfica, a un modelo cultural aristo-

\footnotetext{
34 Ignasi Terrades, El món historie de les masies, Curial, Barcelona, 1984; Andrés Barrera GonzÁlez, Casa, herencia y familia en la Cataluña rural, Alianza Editorial, Madrid, 1970.

35 Jack Goody, Joan Thirsk, Edward P. ThOmpson, Family and Inheritance: Rural Society in Western Europe, 1200-1800, Cambridge University Press, Cambridge, 1976; Walter GoldschmidT, Evalyn Jacobson KunKel, "The Structure of the Peasant Family", American Anthropologist, 73(5), 1971, p. 1058-1076.

36 Lluís To Figueras, "Señorío y familia: los orígenes del "hereu” catalán (siglos X-XII)", Studia historica. Historia medieval, no 11, 1993, p. 57-79; Víctor FARÍAs ZuRITA, El mas i la vila a la Catalunya medieval: Els fonaments d'una societat senorialitzada (segles XI-XIV), Universitat de València, Valencia, 2011.
} 
crático $^{37}$, sino a una elite campesina, lo que los vincula con los ejemplos de las feminae que he considerado antes, cuestión que me parece importante a resaltar, así como el paralelismo cronológico con las primeras pubilles.

Es innegable que en el caso catalán el control personal del señorío y el uso explícito de las relaciones familiares como mecanismo de dominación feudal alcanzó un grado de formalización sin paralelo en todo el ámbito peninsular. Y lo que supone todavía mayor originalidad -no correspondida en ningún otro derecho civil coetáneo- es el papel otorgado a la hija heredera, la pubilla, quien recibirá el patrimonio íntegro. En los capítulos matrimoniales será ella la protagonista, la que aceptará al marido, la que le consentirá la ofrenda de la dote masculina (aixovar) y le hará el aumento de dote (escreix). Pero no es ésta la cuestión más relevante, podríamos pensar que se trata tan sólo de una trasposición de roles, no. Lo más importante es que será ella quien mantendrá el nombre de la familia (su apellido), mientras el marido perderá el suyo. El vínculo entre la casa y el nombre, vía femenina, es algo completamente inusual en el universo europeo occidental de la época. Pensemos que aún hoy en día, al casarse, una mujer en los países de habla inglesa tomaría el apellido de la familia de su nuevo esposo y eliminaría el suyo original, heredado de su padre. Todo ello nos conduce a constatar una especie de matrilinaje, sistema de linaje en el que la adscripción del individuo se realiza por vía materna, por lo que los ancestros familiares principales son parientes de la madre. En muchas sociedades con matrilinealidad el nombre familiar, las propiedades familiares y las herencias provienen de la familia de la madre, tías y abuela. Los hijos de los varones quedan adscritos a la familia de la madre de los hijos no a la del padre. Es obvio que estas mujeres eran feminae antes de la implantación de la institución del hereu, una vez ya impuesto son las dominae. La pubilla, entonces, traspasa su apellido, el de su familia, el del hogar, por encima del hombre que ha entrado como marido en su casa ${ }^{38}$.

\section{El amor cortés y la herejía cátara}

El tercer indicio que nos revela la mejor situación de las mujeres antes del siglo XIII es la exaltación de la mujer en la literatura trovadoresca y el amor cortés. El reclamo de las voces femeninas del pasado para osar colocarlas en el diálogo de hoy, a partir de las propuestas y de las preguntas que suscitan las mujeres actuales, constituye una síntesis de una vía de investigación que ha devenido un logro de los movimientos de mujeres y, a la par, en los ámbitos de la literatura y la historia. Muchas estudiosas de la civilización medieval se han apropiado de esta forma de acercamiento, al darse cuenta que la escucha de las voces de las mujeres medievales desmentía categóricamente la

\footnotetext{
37 Georges Duby, El caballero, la mujer y el cura, Taurus, Madrid, 1982, p. 67-75.

38 Coral Cuadrada, El Maresme Medieval. Hàbitat, Economia i Societat, segles X-XIV, Rafael Dalmau editor, Barcelona, 1988, p. 564-589. En la cabrevación del castillo de Mataró y el de Vilassar, en los años 1354-1362 hay en Mataró un $10 \%$ de pubilles, y en el de Vilassar se eleva al 16,27 \%. En ambos casos las herederas confiesan ante el señor feudal tener sus posesiones como domina et proprietaria.
} 
idea de que entonces sólo existía el silencio. Pero no se trata exclusivamente de los aspectos materiales de la vida, sino que es importante hacer mención también de los más espirituales, de los íntimos. Hay quien dice que las mujeres no podían hablar o sentir en esa cultura bélica: nada más lejos de la realidad. Cierto que hubo silencio, pero además del silencio las palabras fueron dichas y escritas, tuvieron un ámbito de resonancia a veces de relativa amplitud y visibilidad, otras fueron musitadas de manera más callada o imperceptible, aunque por desgracia compartiesen el mismo destino: la condena a su lenta desaparición a través de la hoguera o de la dampnatio memoriae: el olvido, la erradicación de su memoria.

En la Provenza de los siglos del XI al XIII existía una sociedad femenina. Martiniego ${ }^{39}$ dice que ella se ha de entender como el contexto social en el cual se tiene en cuenta la voz de las mujeres. Cuestión que Rivera ${ }^{40}$ amplia señalando que se trata de sociedades en las que las energías femeninas se orientan a favor de otras mujeres. Las trovadoras son la expresión de esta sociedad. Pernoud ${ }^{41}$ afirma que a principios del siglo XIII, la historia la hicieron las mujeres (yo añado que desde el IX al XII ellas también tuvieron roles de singular importancia en los diversos ejercicios del poder). En el XIII bastantes mujeres ejercieron su autoridad ${ }^{42}$ en el campo político y cultural: Leonor de Aquitania, sus hijas María de Champaña y Juana de Tolosa, sus nietas Blanca de Castilla, Constancia e Isembour. Una bella muestra de genealogía femenina que transmite sus vivencias y su voluntad del ser y estar en la esfera pública desde la perspectiva femenina.

Feudatarias occitanas alimentaron cortes en los castillos que ellas administraban, en ellas tenían lugar preferente la amorosa conversación de las trovadoras y de los trovadores, quienes rechazaron la expresión en lengua culta -el latín- y optaron por la lengua materna, mal definida como vulgar. Los hombres compartieron con las mujeres el uso de la lengua materna en la escritura poética, pero seguramente en ella ellas se sentían particularmente a gusto, en casa: era la lengua de la infancia, de lo cotidiano, la lengua que sabían hablar las mujeres en la vida simple y común, alejada de los eventos oficiales, de las fiestas litúrgicas. La lengua del $\operatorname{amor}^{43} \mathrm{y}$, como no, de los sueños y la fantasía ${ }^{44}$. Pues las mujeres se encontraban en una situación que no les requería alejarse de su día a día, de los sentimientos y de la manifestación de ellos a fin de concretarlos en una obra artística. "Más todavía que las novelas, la poesía trovadoresca fue escrita para las mujeres. El amor novelesco, tratado bajo forma de narración en las novelas de caballerías, ocupaba en ellas un lugar secundario; pero formaba el tema central de

\footnotetext{
39 Marirì Martiniego, Las trovadoras, poetisas del amor cortés, Horas y horas, Madrid, 1997, p. 47-48.

40 María Milagros Rivera, "Vías de búsqueda de existencia femenina libre: Perpetua, Christine de Pizan y Teresa de Cartagena”, Duoda, 5, 1993, p. 5.

41 Régine Pernoud, Bianca di Castiglia, ECIG, Génova, 1994, p. 13.

42 Harald Kleinschmidt, Comprender la Edad Media: la transformación de ideas y actitudes en el mundo medieval, Akal, Madrid, 2009, p. 163.

43 Pilar Gonzalbo Aizpuru, Amor e historia. La expresión de los afectos en el mundo de ayer, El Colegio de México, México, 2013, introducción.

44 Luisa Muraro, Lingua materna scienza divina. Scritti sulla filosofia mistica di Margherita Porete, D’Auria, Nápoles, 1995, p. 80.
} 
la poesía de los trovadores. Poesía amatoria compuesta en romance, observa Dante ${ }^{45}$, porque las mujeres no comprendían el latín. En esta cumplida y armoniosa composición entre el dentro y fuera de sí, entre lo privado y lo público, las trovadoras y los trovadores contribuyeron, junto a sus contemporáneos de varias regiones europeas, a la formación de la lengua y al florecimiento de las grandes literaturas occidentales.

Una palabra clave en el nuevo sistema moral y de buena conducta que crearon los trovadores era jovent, que resumía las virtudes cortesanas. Provenía del latín iuvens y designaba la mesnada permanente de un señor, formada por nobles y caballeros sin herencia. Esta clase social desfavorecida fue, seguramente, la que desarrolló esta nueva ideología con el objetivo de integrarse en la sociedad y tener alguna posibilidad de ascenso social: la valía de los nobles no se medía por su fortuna o poder sino por su preu, por su capacidad personal, buena educación, valentía y generosidad. Cuando tenían que cantar al amor, los trovadores utilizaban "la metáfora feudal ${ }^{46}$ ". En una especie de intercambio de papeles, el enamorado era el vasallo y la mujer tomaba el rol de señor, hasta el punto que se la denominaba midons, que quiere decir "mi señor". En las canciones amorosas también entraba en juego una serie de ritos y temas de la jurisprudencia feudal. Era habitual que los trovadores recurrieran a imágenes muy ambiguas que eran al mismo tiempo eróticas y feudales: en el juramento el vasallo juntaba las manos con las del señor, tenía que poner las manos bajo un manto como símbolo de protección y se daban un beso en señal de afecto y buena voluntad.

Esta Provenza que casi parece una quimera, fue también, en los siglos XI y XII, un puente entre la Europa meridional y la Europa del norte, entre el Mediterráneo y el Atlántico, entre el Islam y la Cristiandad, punto de confluencia de las rutas que conducían a Santiago de Compostela o a las cruzadas. Esta apertura al mundo favoreció, sin duda, la nueva concepción de sociedad a la que antes me he referido. Pero a la par a la expansión del catarismo, una religión cristiana fundamentada en la interpretación dualista del mundo y que proclamaba el retorno al cristianismo primitivo. En Occidente, las herejías del año mil abren a las mujeres, de forma manifiesta, el rol de hermana utópica ${ }^{47}$ : las comunidades evangélicas que se dibujan al margen de la iglesia oficial no reclaman otra ley ni disciplina que la imitación de los apóstoles, mezclan hombres y mujeres, como a clérigos, monjes y laicos. Se hunden los tabúes: el culto a las reliquias, imágenes y cruces; las prácticas sacramentales abusivas como el bautizo a menores sin uso de razón; el matrimonio. La cristiana vale tanto como el cristiano.

Un cierto número de detalles concretos indica que los movimientos del año mil o del siglo XI pueden ser ya clasificados de cátaros o pre-cátaros ${ }^{48}$. El catarismo no creía en ninguna razón teológica que conduzca a considerar a las mujeres como seres inferiores

45 Dante, Vita Nuova, XXV.

46 José Manuel Herrero Massari, Juglares y trovadores, Akal, Madrid, 1999, p. 27.

47 DuBy, El caballero..., op.cit., nota 29.

48 Anne Brenon, (1994): "L'héresie en Languedoc aux XIIe-XIIIe siècles: une réligion pour les femmes?", en AAVV, La femme dans l'histoire et la société méridionales, 66 congrès Féd. Historique LanguedocRoussillon, Narbona, p. 103-116. 
o peligrosos, dado que era un cristianismo basado en el Nuevo Testamento, rechazando como malas las narraciones del Génesis, en especial las de la creación de Eva a partir de la costilla de Adán y su debilidad frente a la serpiente seductora. Los buenos cristianos y las buenas cristianas proclamaban la Buena Nueva del Evangelio, la de la bondad de un padre Dios que nada tenía que ver con Yahvé y sus cóleras. Rezaban diciendo: "que todas las almas son buenas e iguales entre ellas, que el diablo sólo había hecho la diferencia de los cuerpos, y que todas se salvarán". El principio de igualdad de la naturaleza de las almas equivalía a que una alma de mujer era igual a la de un hombre, la de un pobre a la de un rico.

En 1143, Évervin, un monje premonstratense de la abadía de Steinfeld, próxima a Colonia, relató en una carta a Bernardo, abad del Císter, el juicio y la condena de los herejes ${ }^{49}$ a los que calificaba de "apóstoles de Satán". Sin duda se trataba de cátaros, los disidentes cristianos que en esas décadas de profundas transformaciones y reformas en el Occidente cristiano se habían propagado por el sur de Francia (Occitania), en el territorio comprendido entre Albi, Tolosa, Carcasona y Foix. Considerándose ellos mismos como los únicos herederos legítimos de la Iglesia de los Apóstoles, los cátaros acusaban a la jerarquía católica de haber traicionado el ideal de vida de las primitivas iglesias cristianas. Según Évervin, estos "apóstoles de Satán" habían captado adeptos por toda la región, y en particular entre la población femenina. "Tanto monjas como viudas, vírgenes y también sus esposas" formaban parte de esta Iglesia herética, "unas en calidad de elegidas, otras como creyentes, siguiendo así el ejemplo de los Apóstoles que estaban autorizados a llevar mujeres con ellos". El testimonio de Évervin refleja una particularidad del movimiento cátaro: el notable protagonismo que en él alcanzaron las mujeres, en contraste con lo que ocurría en la Iglesia católica oficial.

Aunque a partir del siglo IV, las mujeres, y principalmente las diaconisas, pudieron ejercer ciertas responsabilidades y funciones pastorales, el diaconato femenino desapareció dos siglos más tarde, en la época merovingia. Para las mujeres, la vía más accesible de integración en la vida religiosa eran las órdenes monásticas. Sin embargo, los territorios del Languedoc no disponían prácticamente de comunidades femeninas, ni siquiera por parte de las nuevas órdenes religiosas que se fundaron tras la reforma gregoriana en el siglo XI: cartujos, premonstratenses, gramonteses... Ello influyó en la aceptación tan favorable que las mujeres occitanas manifestaron hacia la Iglesia cátara. Muchas acudían a las predicaciones de los "buenos hombres" cátaros (el equivalente a los clérigos católicos). Otras iban más lejos y se integraron en comunidades cátaras femeninas, semejantes en algunos aspectos a los conventos católicos. Así, hacia 1200, las mujeres de la mediana aristocracia de los castillos de Carcasona y de Tolosa, casadas, viudas o solteras, podían entrar en la Iglesia cátara como "buenas mujeres". Cuando recibía el consolamentum, la futura "buena mujer" pronunciaba los votos monásticos de la regla cátara: obediencia, ascesis y pobreza.

49 Anne Brenon, "La lettre d'Evervin de Steinfield à Bernard de Clairvaux de 1143: un document essenciel et méconnu", Heresis, 25, 1995, p. 7-28. 
Dentro de la economía general de la Salud cristiana cátara ${ }^{50}$, la mujer gozaba, por tanto, del mismo lugar que el hombre. Y, a pesar que las condiciones socioculturales del desarrollo del cristianismo cátaro hacían muy difícil que se generara algo que superara la misoginia creciente, es incuestionable que dejó a las mujeres el papel, impensable en el contexto católico, de mediadora de Salud. La cristiana cátara tenia el poder de redimir los pecados, de la misma forma que lo tenían, desde el siglo X, las mujeres bogomilas. Papel cuasi sacerdotal, bien diferente del que la iglesia católica concedió a las mujeres, al otorgarles el derecho de bautizar a un moribundo, siempre y cuando se hallara en ausencia de hombre. No es sólo por esta causa que una gran población femenina se integró en este cristianismo austero, sino porque les abría la puerta de la aventura espiritual personal, con los medios para llevar a cabo una vida cristiana consagrada sin estar sujetas a un poder masculino, asegurándose a la vez su propia subsistencia a través del trabajo comunitario ¿No es ésta una verdadera acción política? En el sí de las comunidades cátaras, numerosas, laboriosas y abiertas, era bien seguro que parecía, a los ojos de las occitanas, más fácil ser cristianas, conseguir la Salud de su alma y de la de los otros. La historia muestra que las mujeres del Lenguadoc se mantuvieron, hasta el final y a pesar de todos los peligros, fieles a la causa del catarismo perseguido. A finales del siglo XIII y en los primeros años del XIV, después de la desaparición forzosa de las comunidades de Buenas Mujeres y cuando el catarismo agonizaba, las creyentes tomaron el relevo a los hombres, en proporciones que analiza de forma muy interesante el estudio de Abels y Harrison ${ }^{51}$. Devotas buenas creyentes como Sibila Baille, d'Aix-les-Thermes; o Montoliva Francés, de Limoux, consagraron hasta la pira su coraje por la causa perdida de su iglesia destrozada por la Inquisición. Una última buena mujer, Auda Bourrel, murió en Toulouse en 1307: sus restos mortales fueron exhumados y quemados un año más tarde. La más tardía de la que se tiene constancia, se llamaba Guillema Tournier: fue quemada viva en Carcassona en $1325^{52}$. Según Weil ${ }^{53}$, los cátaros, "Llevaron su horror por la fuerza hasta la práctica de la no violencia y hasta la doctrina que hace proceder del mal todo lo que es dominio de la fuerza, es decir, todo lo que es carnal y todo lo que es social. Lo que es ir lejos, pero no más lejos que el evangelio."

Los cátaros y los trovadores convivieron durante más de dos siglos en las mismas regiones occitanas, especialmente en los condados de Tolosa y Foix y en el vizcondado de Carcasona. Participaban de la misma civilización, formaban parte de la misma sociedad y muchas veces sus intereses se confundían, ya que solían tener los mismos protectores nobles. En los castillos, los Bonshomes y los poetas, hablaban ante el mismo

50 Teresa Ruiz RoIG, "Las cátaras: una reflexión sobre oralidad y escritura", Duoda. Revista d'Estudis Feministes 7, 1994, p. 119-124

51 Richard Abels, Ellen Harrison, "The participation of women in languedocian Catharism", Medieval Studies, 41, 1979, p. 215-251.

52 Robert Ian Moore, La guerra contra la herejía. Fe y poder en la Europa medieval, Crítica, Barcelona, 2014.

53 Simone WeIL, Écrits historiques et politiques, Gallimard, París, 1960, p. 83. 
auditorio de caballeros y damas. Sus ideologías respectivas, aunque muy opuestas en cuanto al fondo, presentaban algunos puntos de curiosa convergencia sobre todo en lo concerniente al problema del matrimonio. Dicha particularidad consiste en que, por primera vez, dos doctrinas absolutamente opuestas, el catarismo y el amor cortés, tienden a liberar a la mujer anulando la noción de pecado carnal ${ }^{54}$. "Amor no es pecado, sino virtud", decían los trovadores. En cambio, los cátaros sentenciaban: "es siempre pecado para los perfectos pero no para los simples creyentes". Así, las mujeres aprovecharán esta doble enseñanza para reivindicar el derecho a amar a su manera y en afirmar su independencia frente a la potestas masculina. Indiscutiblemente, para las mujeres de la nobleza del siglo XII, el libertinaje, al igual que el ascetismo pero en sentido inverso, constituyó una protesta inconsciente contra el orden social que las coaccionaba y sobre todo contra el matrimonio que solía favorecer a los hombres. Si querían afirmar su autonomía, las damas tenían acceso a escoger el camino propugnado por los trovadores, en el que predominaba la libre idea de que el amor no es pecado, o bien, por el contrario el camino aconsejado por los Buenos Hombres donde el ascetismo y la perfección, es decir, el amor en su grado máximo de pureza, fue más asequible a todo tipo de mujeres, sin importar la capa social de la que procedían.

De tal manera hay que afirmar que "el amor provenzal" se desarrolló paralelamente al catarismo, en las mismas regiones occitanas, y que durante el largo transcurso de dos siglos, las dos doctrinas llegaron a coexistir. Los documentos del siglo XIII nos revelan cómo gran parte de las damas de las regiones occitanas que acogían y protegían los trovadores, eran asimismo creyentes o simpatizantes del catarismo en vísperas de la Cruzada Albigense. Se puede pues pensar que no veían ninguna contradicción entre las teorías poético-eróticas de sus trovadores y la filosofía moral de los Bonshomes. La mayoría de ellas estaban seducidas por la novedad de la doctrina cátara y se interesaban por las discusiones metafísicas y generalmente mostraron más a menudo un claro acercamiento a la herejía que por parte de sus propios maridos. Mientras que la mayor parte de los señores y caballeros occitanos se decantaban por una revuelta contra las posesiones eclesiásticas ya que para ellos era una magnífica ocasión para expoliar los bienes de los clérigos romanos; en cambio, ellas fueron consecuentes con sus compromisos con la iglesia cátara ya que a pesar de la terrible persecución, prefirieron morir en las hogueras con una fe y un coraje dignos de admirar.

\section{La feminidad: Eva, María y Magdalena}

El cuarto indicio de empeoramiento de la condición de la mujer en la Edad Media central y centurias siguientes viene de la difusión del culto mariano por la Iglesia, a partir del siglo XII, lo que comportó consecuencias terribles para las mujeres. Cierto

54 Jean Verdon, El amor en la Edad Media: la carne, el sexo y el sentimiento, Paidós, Barcelona, 2008, p. $22-25$. 
es que el pecado de Eva no era nuevo, la novedad se hallaba en reciclar el mito con toda clase de ensañamientos. La concepción de la mujer por parte de los pensadores medievales se basó en la creencia en su inferioridad, filosofía que surge como resultado del pecado de Eva ${ }^{55}$. El sector social que defendió esta ideología estaba capitaneado por los padres de la Iglesia, que exaltaban la gloria de la virginidad en la mujer. Exaltación que enfatizó la admiración hacia la imagen de la Virgen María, caracterizada también por su compasión y preocupación maternal ${ }^{56}$. La mayoría de las mujeres, por tanto, eran consideradas hijas de Eva, hijas del pecado, y contrastaban con una minoría que encarnaba la figura de María -las monjas que, curiosamente, sólo eran vírgenes, no madres. Esta idea perduró durante la edad media, donde se argumentó hasta el agotamiento la oposición entre Eva y María ${ }^{57}$, llevada a todos los ámbitos de la sociedad y traducida según criterios de orden y de desorden, con la contemplación paradisíaca por un lado, y con los castigos impuestos a las desviaciones, por el otro. La figura de María durmió en el imaginario hasta el siglo XI, presentándose más tarde como una mujer divina e inaccesible. Su imagen se vinculó más que como redentora y salvadora a la gracia divina de madre y virgen: pureza inviolada que superaba la ambigüedad de la virginidad. La virginidad, pues, junto a la maternidad, devienen los dogmas marianos más importantes, ya sea por su trascendencia a nivel ideológico, ya sea por los roles específicos que implicaban. La presencia mariana adquirió una gran fuerza ideológica y moral para el pueblo. María no era mujer, era sólo madre y virgen. De esta manera se dividió la sexualidad femenina entre las vírgenes y las que no lo eran-casadas o viudas. La sexualidad se convirtió en el eje definitivo de la consideración femenina a partir del culto mariano.

Especialmente sugerente me resulta la concepción de María como nueva Eva encargada de abrir las puertas del Edén. A partir de la contraposición tipológica Eva-María (Eva-Ave) la exégesis medieval desarrolló la idea de la Virgen como puerta abierta del Paraíso. La madre de Dios, intercesora que abre las puertas celestiales aparece, por ejemplo, en un fragmento del poema De Sobrietati de Milon de Saint-Amand (+871): "Oh Virgen María, [...] puerta cerrada, mansión de la que sólo el fundador salió, tu abres las puertas del Paraíso que Eva cerró al coger la manzana venenosa del árbol ${ }^{58 "}$. Este concepto es también desarrollado en un sermón de finales del siglo X compuesto

\footnotetext{
55 Francisco Ruiz Gómez, "La identidad en el discurso religioso", en José Antonio JARA Fuente et alii, Construir la identidad en la Edad Media: Poder y memoria en la Castilla de los siglos VII a XV, Universidad de Castilla La Mancha, 2010, p. 24.

56 Joaquín Benito de Lucas, Poesía y religiosidad en la Edad Media castellana, Rialp, Barcelona, 2011.

57 La teología sobre la Virgen ha sido profusamente tratada y con muy diversos planteamientos. Una obra clásica sobre María en Marina WARnER, Tú sola entre las mujeres. El mito y el culto de la Virgen María, Taurus, Madrid, 1991. Sin embargo, los estudios sobre la Virgen aportan nuevos e interesantes planteamientos, cfr. Cristina PAPA, "'Car vos senyora sou la gran papesa'. Mariologia e genealogie femminili nella Vita Christi di Isabel de Villena", en María del Mar GraÑa CID (ed.), Las sabias mujeres: educación, saber y autoría (siglos III-XVII), Asociación Cultural Al-Mudayna, Madrid, 1994, p. 213-222. Para aspectos generales cfr. Amy Jill Levine (ed.), A Feminist Companion to Mariology, T. \& T. Clark, London-New York, 2005.

58 Henry BARre, “Antiennes et répons de la Vierge”, Marianum, 29, fasc. 91-93, 1967, p. 225. Mi elipsis.
} 
en el círculo de Odón de Cluny (+924): Sicut per Evam omnes morimur, ita per Mariam omnes vivificamur. Paradisi namque porta per Evam cunctis clausa est, et per Mariam virginem iterum patefacta est ${ }^{59}$.

Una de las mujeres más remarcables del siglo XII, Hildegarda de Bingen, no participa de esta visión dicotómica y pesimista de una de las figuras femeninas ${ }^{60}$. Aunque ella no trata ex profeso las cuestiones teológicas, no duda en exponer las enseñanzas recibidas del Cielo en sus visiones del Liber Scivias y del Liber divinorum operum. Así, esta monja hace el elogio del matrimonio, y declara que la grandeza del rol de la mujer consiste en parir y en educar los hijos e hijas. La mujer -dice- en el momento de la creación, es una mujer perfecta, tal como Adán es un hombre perfecto, uno y otra en estado de engendrar y de traer un niño al mundo. El hecho de que la primera mujer fuera formada de la substancia del hombre es la marca de la unión conyugal de la mujer y el hombre, conjunción instituida por Dios; el matrimonio es bueno en sí, y eso perdura hasta sus días; el hombre y la mujer se convierten en una sola carne en una unión de amor para la propagación del género humano. Están vinculados hasta tal punto que no se puede concebir uno sin la otra. Así, Hildegarda, junto a Herralda de Hohenburg, defiende lo que la filósofa Prudence Allen ${ }^{61}$ ha llamado la "teoría de la complementariedad de los sexos" que dice que las mujeres y los hombres somos sustancialmente diferentes y somos iguales. Hildegarda se permite incluso modificar los términos de la primera epístola a los Corintios para sustentar su tesis: Mullier propter virum creata est et vir propter mulierem factus est..., a fin de que no se separen y resten uno en su descendencia, in unitate natorum suorum ${ }^{62}$. En ello Hildegarda no se separa de la doctrina común en su época, la prole es el bien principal del matrimonio.

¿Podemos entonces entender a Hildegarda como una defensora de los derechos de la mujer? No, ella reconoce la debilidad de su sexo, en base a la cual la situación respecto al hombre es como la de la luna, que recibe la fuerza del sol, es decir, del hombre; la mujer debe serle sumisa y estar siempre presta a servirle, ya que el hombre la necesita; es gracias a la habilidad de las manos femeninas que él puede ser vestido ${ }^{63}$. No cita la cocina, pero admito que se sobreentiende, lo que expone es la incapacidad masculina para proveer al mantenimiento de los suyos. Dios ha reunido el hombre y la mujer, a quien es fuerte y débil para que se sostengan mutuamente. Sin embargo, a causa de esta debilidad reconocida de su sexo, Hildegarda se opone enérgicamente al sacerdocio de

\footnotetext{
59 Natacha Piano, "De la porte close du temple de Salomon à la porte ouverte du Paradis: histoire d'une image mariale dans l'exégèse et la liturgie médiévales IVe-XIIIe siècles", Rivista della Fondazione Centro Italiano di Studi Sull'Alto Medioevo, 2009, p. 133-157.

60 Prudence Allen, The Concept of Woman. The Aristotelian Revolution, 750 BC-AD 1250, Eden Press, Montreal \& Londres, 1985; Barbara Newman, Sister of Wisdom: St. Hildegard's Theology of the Feminine, University of California Press, Berkeley \& Los Angeles, 1987.

${ }_{61}$ Prudence Allen, The Concept of Woman. The Aristotelian Revolution, 750 BC-AD 1250, Eden Press, Montreal \& Londres, 1985.

${ }^{62}$ Hildegardis Scivias, edición Adelgundis FührKötter y Angela CARLeVAris, Brepols, Turnhout, 1978. II, visio 5, PL, CXCVII, p. 392 y ss.

${ }_{63}$ Liber divinorum operum, Lucca, Biblioteca Statale, Ms. 1942, I, visio 4, ibid., 851.
} 
las mujeres ${ }^{64}$, la prohibición es pronunciada por Dios mismo en una de sus visiones: las mujeres no pueden acercarse al altar porque son un infirmum et debile habitaculum, "una pequeña residencia débil y enferma"; ellas están hechas para traer al mundo y alimentar los niños, no para decir misa. Es necesario que cada quien esté en su lugar, es por este motivo que reprueba vivamente los travestis, las mujeres no deben disfrazarse de hombres, ni los hombres de mujeres; la fuerza viril de unos, la fragilidad femenina de las otras han de ser remarcadas en los vestidos. Esta regla vale salvo en los casos graves, si el hombre está en peligro de muerte o la mujer en riesgo de perder su virtud. Hildegarda se complace a pesar de todo en resaltar las cualidades de la mujer, y declara especialmente que ella es más dulce y amable que el hombre-suavior ${ }^{65}$-; pero lo fundamental es que ella asume la defensa de su sexo contra las despectivas afirmaciones de los naturalistas, quienes pretenden que la mujer es más libidinosa que el hombre ${ }^{66}$. No, -asegura la monja- la mujer tiene un humor húmedo que se combina con el calor para hacerla apta a concebir, pero la concupiscencia está lejos de ser tan fuerte y tan ardiente en ella como en el hombre, al que se puede comparar a la fuerza del león, mientras que la mujer está más que nada ocupada en procrear criaturas y traerlas al mundo. Desafiando el latín más fácilmente las conveniencias, prefiero citar a Hildegarda en esta lengua:

In illa non est iam fortis et iam fervens concupiscentia sicut in viro, qui fortis est ianquam leo ad concupiscentiam operis filiorum, ita quod ipse habeat fortitudinem concupiscentiae ac operis, muliere tantum hoc negocium habenti quod subiacet imperio voluntatis illius, quoniam ipsa occupata est in procreatione natorum, usquedum eos producet in mundum.

A partir del siglo XIII se percibe un cambio en las mentalidades y en la vida debido a la conjunción de diversos factores religiosos y sociales: la fuerte influencia de la corriente misógina fomentada desde las filas de la Iglesia — principalmente a través de los escritos de los Santos Padres y de los sermones-, el desarrollo de la burguesía y la restauración y florecimiento de la vida urbana que coincide con la laicidad de la vida intelectual - universidades. En consecuencia, se rechazan los valores predominantes en la centuria precedente: frente a la idealización cortés de la mujer se opone el realismo y el antifeminismo; frente a los valores religiosos se oponen los valores anticlericales y frente al poder aristocrático se opone el antifeudalismo burgués. Así pues, la misoginia condena a la mujer como símbolo de lo corporal y sexual y, por ello, de lo material y efímero. Frente a la castidad, a la pureza y a la virtud, la mujer aparece, descendiente de Eva, como una mujer lasciva, taimada, mentirosa, capaz de engañar al marido de mil modos diferentes, siempre para su propio provecho. Esta concepción tan negativa

${ }^{64}$ Hildegardis Scivias, op.cit. nota 40, II, visio 6, ibid., p. 545-546.

65 Ibid., III, visio 3, ibid., 595.

${ }_{66}$ Ibid., II, visio 5, ibid., 461. 
de la mujer pronto se hace eco en el terreno literario; baste solamente con mencionar los fabliaux, autores como Jean de Meung, o nuestros marqués de Santillana y Jaume Roig. Así, el androcentrismo no encuentra otra forma de justificar su propia concupiscencia y lascivia que convirtiéndola en seducción y provocación femeninas: no es que el hombre tenga una tendencia viciosa al sexo, es que es provocado.

Eva, entonces, es la pecadora, la diabólica, la caída... la sierpe. Detrás de ella vive el pecado, la mujer será la culpable de la condena, desde el inicio y durante largos siglos de historia de la humanidad. Ella esconde, como cuentan los eclesiásticos, el pecado, el engaño y la ambigüedad. Eva, virgen e intacta, habiendo aceptado la palabra de la serpiente, dio pie a la desobediencia y a la muerte. Es ella quien cargará con la desazón de Yahvé: "multiplicaré tus dolores en tus preñeces; con dolor parirás los hijos, y estarás bajo la potestad de tu marido y él te dominará67". Como consecuencia de desestimar la prohibición, Yahvé Dios expulsó a la pareja de los jardines del Edén y fue entonces cuando la mujer fue nombrada por su marido: "llamó Eva a su mujer, por que ella fue la madre de todos los vivientes ${ }^{68}$.

Origen del hombre en la tierra, principio y causa de su desgracia, Eva es la tentadora del varón, persuadida por su semejante, la serpiente, cuya imagen se representa la del Diablo: "la mujer es quien ha sido la autora de la falta para el hombre, no el hombre para la mujer". Entonces el dictamen se impartirá a todas las mujeres por igual: “¿No sabes que también tu eres Eva? La sentencia de Dios conserva aún hoy todo su vigor sobre este sexo, y es menester que su falta también subsista. Tú eres la puerta del Diablo, tú has consentido a su árbol, tú has sido la primera en desterrar la ley divina". La iglesia medieval necesitará, entonces, separarse de la mujer, rechazar la carne, "lo moralmente horrible desde el origen y cuya belleza superficial constituye el peor de los señuelos", iniciando lo que Dalarun ${ }^{69}$ llama "un combate de envergadura" a fin de impulsar la reforma de las costumbres eclesiásticas. Así Eva, deja de ser nombrada en los claustros y la apreciación de su espíritu se caracterizará por distintos epítetos:

la mujer una cosa frágil, nunca constante, salvo en el crimen, jamás dejará de ser nociva espontáneamente. La mujer, llama voraz, locura extrema, enemiga íntima, aprende y enseña todo lo que puede perjudicar: La mujer, vil foro, cosa pública, nacida para engañar, piensa haber triunfado cuando puede ser culpable. Consumándolo todo en el vicio, es consumida por todos y, predadora de los hombres, se vuelve ella misma su presa.

Génesis 3, 16.

Génesis 3, 20.

69 Jacques Dalarun, "La mujer a ojos de los clérigos", en Georges Duby y Michèle Perrot (coord.), Historia de las mujeres. Edad Media, Taurus, Madrid, 1992, p. 419-439. 
En cambio, María, habiendo concebido con fe y alegría, cuando el arcángel san Gabriel le anunció que el Espíritu Santo vendría sobre ella, dio pie a la remisión del pecado y la salvación.

Veamos el siguiente cuadro-resumen:

\begin{tabular}{|l|l|}
\hline Eva & María \\
\hline era virgen, tenía un compañero & era virgen, casada con José \\
\hline $\begin{array}{l}\text { fue seducida para hacer el mal } \\
\text { MENTIRA }\end{array}$ & $\begin{array}{l}\text { recibió la gran noticia: engendrar a Jesús } \\
\text { VERDAD }\end{array}$ \\
\hline desobedece & obedece \\
\hline es causa de la muerte & es causa de salvación \\
\hline ató la libertad del hombre & liberó al hombre \\
\hline falta de fe & obedece por la fe \\
\hline huye de la presencia de Dios & vive con Dios \\
\hline $\begin{array}{l}\text { por una virgen la humanidad es } \\
\text { sentenciada a muerte }\end{array}$ & $\begin{array}{l}\text { por una virgen la humanidad es } \\
\text { salvada }\end{array}$ \\
\hline
\end{tabular}

En la estereotipada división entre Eva y María se puede establecer un esquema divisorio de conductas práctico-morales, basadas en los vicios y virtudes de las mujeres. Las conductas negativas son las propias de Eva; las positivas suponen que María encarna el modelo a seguir, el ideal de la mujer medieval. La sociedad en la Edad Media se constituyó como resultado de una serie de dualidades, siendo una de las más significativas la contienda que se dirimió en el interior del cuerpo mismo, en la que según la concepción cristiana "el cuerpo es despreciado, condenado, humillado ${ }^{70 "}$. Así, la mujer, culpable, en la que se compendian los pecados de la carne y la sangre, Eva en todas las mujeres, dejará de ser nombrada como tal, producto de la etimología de su nombre: "Eva es Vae, la desgracia, pero también la vida"; "Eva es Ave que otrora lanzara Gabriel a la nueva Eva y evocar a Eva es invocar a María.". Lo innombrable, entonces, debe ser salvado. Lo misógino, redimido. Para dirimir a la mujer del mal tan grande al que ha dado origen, es necesario instituir un bien igualmente grande originado en una mujer. Al pecado de Eva innominada, se opone la redención de María, inaccesible. Sin embargo las fervientes alabanzas a la Virgen Madre no significaron un homenaje para el resto de las mujeres, María deja de ser un modelo cercano para protegerla en el cielo inalcanzable de una maternidad virginal sin la menor fisura. Entonces, ¿qué proponen a las mujeres de este mundo? La respuesta se simplifica en la imitación del modelo mariano: la preservación de la virginidad. Así surge la figura de la santa que, aunque tímidamente, rehabilita a la mujer en su función social, pese a no poder hablar de su salvación. María ha dado a luz a Cristo y como madre de Cristo, es madre de

70 Jacques Le Goff, Nicolas Truong, Une histoire du corps au Moyen Age, L. Levi, Paris, 2003, p. 12. 
todos los cristianos: madre de todos los que viven por la gracia, en oposición a Eva, madre de todos los que mueren por la naturaleza, y todo tiene lugar en el vientre de una madre cerrada para todos salvo, misteriosamente, para uno. La figura de Eva, en caso de no ser borrada, era compensada por la de la Virgen María, lo que permitirá el surgimiento de una tercera figura, la de María Magdalena, el camino de la penitencia y el arrepentimiento de la pecadora.

Si el camino virginal ya no era factible, ¿qué posibilidad de salvación ofrecía entonces la iglesia a las mujeres? La única dirección posible era dada por la redención: "no hay apelación posible para la pérdida del sello virginal, ni en lo físico, ni en lo moral. El único camino es la penitencia, el arrepentimiento de la pecadora, de la meretrix". La redención del alma pecadora está dada en la confesión de las faltas siguiendo el modelo de María Magdalena penitente y como el alma tiene género femenino, es lógico que una pecadora femenina sea la que oriente al pecador arrepentido. Magdalena, la pecadora que "se puso por detrás, junto a sus pies, y llorando, comenzó a regarlos con sus lágrimas y los enjugaba con los cabellos de su cabeza, los besaba y ungía con el perfume ${ }^{71}$ ", peca a través de la carne, peca a través de su esencia femenina, por lo que su salvación sólo es posible mediante el arrepentimiento de la carne culpable. "Dividida entre la esperanza y el miedo se convierte en 'acusadora de sus pecados' y es precisamente su redención lo que la salva". Cristo la recibe y la redime, Magdalena se convertirá en la pecadora que anuncia la resurrección "esto se hizo para que la mujer que llevó la muerte al mundo no quedara en el oprobio, de la mano de la mujer, la muerte pero de su boca el anuncio de la Resurrección".

La Iglesia la transforma en metáfora ${ }^{72}$, Magdalena es, además de pecadora, quien abre las puertas del cielo a todo aquel que desee arrepentirse ${ }^{73}$, la mujer gloriosa que "ha curado no solo sus heridas, sino las de muchos pecadores, y no deja de curarlos cada día". Disociada de Eva, la mujer despreciable que debe ser alejada, y de María, la figura inmaculada que queda fuera de todo alcance mundano, Magdalena se inviste del sentimiento de conciencia: "entre la puerta de la muerte y la puerta de la vida, la bienvenida pecadora es una puerta entreabierta a una redención posible, pero al precio de la redención, del arrepentimiento, de la penitencia”, y la penitencia será en el caso de la mujer doblemente costosa: redimirse del pecado y de su condición de mujer.

Paralela al culto mariano la sacramentalización del matrimonio. La Baja Edad Media fue una época de profundos cambios demográficos, económicos, sociales y culturales, en la que tuvieron lugar hechos de enorme trascendencia. Uno fue el interés despertado por el derecho romano y por la renovación del derecho canónico, que, en opinión de los reformistas, debería desempeñar un papel fundamental en el gobierno de la sociedad cristiana. El resultado fue la elaboración de toda una serie de compilaciones canónicas,

71 Evangelio según San Lucas, 8, 38.

72 Katherine L. JANSEN, The Making of the Magdalen. Preaching and Popular Devotion in the Later Middle Ages, Princeton University Press, Princeton, 2000.

73 Enriqueta Zafra, Prostituidas por el texto: discurso prostibulario en la picaresca femenina, Purdue University Press, Indiana, 2009, p. 65-74. 
de las que la más influyente fue, sin duda, el Decretum de Graciano, maestro de teología en Bolonia hacia 1140. Acoge un esbozo de moral sexual, fundamentado en la premisa de que el sexo sólo era lícito en el matrimonio y siempre que estuviese destinado a la procreación y nunca al simple placer. Todo sexo extramarital era no sólo pecaminoso, sino delictivo y sujeto al castigo de las autoridades eclesiásticas ${ }^{74}$. Voy a aproximarme a la imagen de la situación de la mujer dentro del matrimonio ¿Es ese retrato un fiel exponente de la realidad social o distorsión de ésta? Recordemos que la corriente cortés del siglo XII recubrió la relación hombre-mujer con un barniz idealista: la mujer de belleza sin par y modales exquisitos estaba adornada con todas las virtudes posibles. Todas estas excelencias la convertían en la domina y sus enamorados la servían fervientemente. La dama en la literatura cortés aparecía, por lo tanto, en una posición de poder que le permitía entregarse "libremente" al verdadero amor que, según la fin 'amors, sólo se encuentra al margen de las imposiciones familiares y de las convenciones morales y legales. Por todas estas razones, la relación marital era sustituida por la relación entre los amantes, de manera que pocas son las escenas de intimidad conyugal en esa literatura.

Sin embargo, los historiadores de la Civilización medieval, especialmente Le Goff y Duby, nos dicen que los escarceos de galantería de esta época nunca fueron más que un simulacro mundano, un hermoso ropaje arrojado sobre la verdad de las actitudes afectivas. Para Duby ${ }^{75}$ se trataba tan sólo de un juego, pero de un juego específicamente masculino, como masculina es también la literatura que exalta los valores viriles, y en la que la mujer es el "señuelo" de una competición permanente entre los jóvenes caballeros casaderos de la sociedad aristocrática. En cuanto al matrimonio en la Alta Edad Media, la mujer podía ser repudiada a conveniencia del marido, aunque se esgrimieran causas legales o morales para justificar la disolución del matrimonio ${ }^{76}$. Incluso, durante los siglos X, XI y XII -y en cierta manera hasta mucho más adelante-, el adulterio era considerado causa de pena capital para la mujer, nunca para el marido al que permisivamente la tradición le permitía concubinas ${ }^{77} \mathrm{y}$ amantes; dicho de otro modo, el adulterio era un delito femenino. En cuanto a la mujer casada, su situación no se ha modificado sustancialmente ya que sigue siendo una persona jurídicamente carente de derechos al depender de su marido, al que está sometida ${ }^{78}$. En el matrimonio, el marido es superior a la mujer. Es el dueño de la casa y de los bienes, aunque estos sean los de la esposa y la ley le reconoce, además, el derecho a disponer de su cuerpo. En el ámbito burgués hay una mayor relajación o libertad, por ejemplo en relación con el adulterio, pues no

\footnotetext{
74 James A. Brundage, La Ley, el sexo y la sociedad cristiana en el Europa medieval, Fondo de Cultura Económica, México, 2000, p. 262-263.

75 Duby, El caballero..., op.cit., nota 29, p. 47.

76 Entre estas causas están el adulterio de la mujer y/o su supuesta esterilidad.

77 La Iglesia a través de sus canonistas (Graciano entre otros) condena sin paliativos el concubinato, sin embargo, la concubina poseía un status "oficial" regido por contrato y con derechos consolidados. Vid. Leah OTis-Cour, Historia de la pareja en la Edad. Media, siglo XXI, Madrid, 2000.

78 Como sabemos, el Génesis dice que Eva fue creada de una costilla de Adán, esto justifica el sometimiento de la mujer al hombre de por vida. Tutelada primero por el padre, luego lo será por el marido y, ya viuda, sus derechos serán ejercidos por otros hombres: hermanos, parientes, etc.
} 
existe el problema de la legitimidad de los hijos en relación con la herencia del feudo familiar que en las clases aristocráticas, en cambio, resulta de vital importancia para evitar que el patrimonio acabe en poder de los bastardos.

De una manera esquemática, cabe describir así el proceso:

- Hasta el siglo cuarto el matrimonio era un acontecimiento civil, considerado santo por celebrarse entre cristianos.

- Entre los siglos IV y XI se fue desarrollando una liturgia, no obligatoria, que se añadía al matrimonio civil.

- A partir del siglo XI la ceremonia civil tendió a celebrarse en la iglesia.

- El proceso se completó en los siglos XI-XII, cuando el matrimonio civil acabó absorbido por la liturgia religiosa, dejando de percibirse en su densidad propia.

Al parecer se debe a Anselmo de Laon y a su escuela de teología el primer tratado sistemático del matrimonio como sacramento ${ }^{79}$. Constaba de los siguientes apartados: origen e institución del matrimonio; fines del matrimonio; bienes; cuestiones relativas a la forma y efectos del matrimonio. En cuanto a la institución afirma que fue instituido en el paraíso y que tuvo una confirmación con la presencia de Cristo en las bodas de Caná. Por tanto su carácter sacramental queda dado por ser signo de la unión de Cristo con su Iglesia: la consecuencia es que sólo el matrimonio celebrado en la Iglesia es santo. El elemento determinante sería el consentimiento de los cónyuges.

A lo largo de la Edad Media tiene lugar un esfuerzo sin precedentes capaz de dar respuesta a los grandes interrogantes del momento, planteados, sobre todo, por los errores que renovaban las antiguas doctrinas gnósticas (valdenses, cátaros, albigenses), y también por el permisivismo sexual a que llevaba el ideal del amor puro y romántico -sin procreación- que cantaban los trovadores. La sacramentalización del matrimonio en el IV Concilio de Letrán (1215-1216) supuso un cambio fundamental en relación con etapas anteriores. Se acepta y se declara sagrado, monogámico e indisoluble, pero ello no quiere decir que también se admitiese el sexo. Antes bien, los reformadores se propusieron limitar el sexo marital y castigar tan severamente como pudieran el extramarital, reiterando la necesidad de abstinencia periódica, condenando las prácticas coitales "antinaturales", como el retro canino y el mulier super virus, y prohibiendo cualquier experimentación sexual, incluida el uso de afrodisíacos. El acto sexual era una terapia para el deseo. El placer no era natural ni era el fin de la relación sexual, que sólo estaba permitida si buscaba la procreación.

En continuidad con la patrística, en la teología de la época es común justificar las relaciones conyugales cuando se buscan con la intención de la procreación, y afirmar

79 Domingo Moreno Ramírez, Relevancia de la sacramentalidad del matrimonio en relación con la nulidad del consentimiento, Ediciones San Dámaso, Madrid, 2014; Tomás Rincón, Eutiquian Saldón, Eloy TeJero, El Matrimonio, misterio y signo: Siglos IX-XIII, Universidad de Navarra, Pamplona, 1971, p. 123-124. 
que habría pecado venial en el caso de que se pretendiera tan sólo evitar la fornicación. En santo Tomás, con san Agustín, los bienes de la prole, la fidelidad y el sacramento son una expresión adecuada del matrimonio. Los dos primeros determinan la bondad natural del matrimonio, de tal manera que lo hacen perfecto en su orden. El sacramento presupone esa bondad primera y la eleva a un orden superior, el sobrenatural. Los tratados de Buenaventura y de Tomás de Aquino son los que más influyeron en la formación teológica del período. Hasta los teólogos dominicos, muchos consideraban el matrimonio desde el punto de vista de la contención de la concupiscencia, dejando así la gracia del sacramento como una gracia negativa. Sin embargo, Alberto Magno y Tomás de Aquino consideran que la gracia propia del sacramento está relacionada con la vivencia de éste: la fidelidad, el amor y entendimiento mutuo, la educación religiosa de los hijos, etc.

Pero los verdaderos cambios de progreso en la concepción femenina y en política matrimonial llegan a finales de la Edad Media. En los siglos XIV y XV comienza a instaurarse un sentir más profundo de búsqueda de nuevos valores, posiblemente como atisbo de la modernidad que traerá consigo el Renacimiento ${ }^{80}$. Efectivamente, aunque la misoginia sigue atrincherada en ciertos sectores de la sociedad, lo cierto es que se aprecia una mayor consideración por la mujer y por lo femenino. La literatura de la época se hace eco en autores y obras que ensalzan las virtudes y capacidades de la mujer. Recordemos entre otros muchos a Boccaccio con su De mulieribus claris, una obra de alabanza a la mujer que será imitada por diversos autores de los siglos XV y $\mathrm{XVI}$; recordemos también que en ocasiones son las propias mujeres las que asumen su defensa y dejan oír su voz con valentía en un mundo todavía de hombres. Nos referimos a Christine de Pisan y especialmente a su obra la Cité des Femmes (1405) en la que proclama -invirtiendo la corriente que denuesta el cuerpo femenino- que las mujeres "debían dar gracias a Dios por haber depositado el tesoro de sus almas en cuerpos femeninos".

Esta apreciación de la mujer se deja sentir especialmente en el matrimonio, aunque aparentemente todo parezca que sigue igual. El papel tradicional de la mujer se modifica al ser las relaciones entre los cónyuges más flexibles. Los maridos confían en la capacidad de su mujer para llevar la casa, educar a los hijos e incluso asumir responsabilidades jurídicas en su ausencia: la esposa podía realizar transacciones comerciales o patrimoniales. Esta asunción de poder era muy frecuente en la clase burguesa en la que el matrimonio se concebía como una asociación de bienes comunes. En las clases aristocráticas son frecuentes los matrimonios "hipérgamos" (matrimonio de un hombre con una mujer de estatus superior), en los que la esposa administra generalmente la dote y los bienes de la pareja. La literatura cortesana bajomedieval introduce a menudo esta realidad en el topos literario de la esposa de clase superior al esposo. Todos estos aspectos desembocarán en lo que conocemos como la Querelle des femmes...

${ }_{80}$ Coral CuAdrada, El llibre de la pesta, Rafael Dalmau editor, Barcelona, p. 199-204. 


\section{Líneas finales}

No titulo estas breves reflexiones últimas como conclusión porque no creo que lo sean. Sí, es cierto, a lo largo de mi exposición he analizado en profundidad algunos de los motivos que llevaron a las élites intelectuales medievales a endurecer sus discursos sobre las mujeres, desde los ámbitos de la religión y el derecho, principalmente. He estudiado las pervivencias de una matrilinealidad en distintas regiones de España en la época tardo-romana y altomedieval. He seguido las huellas de esas mujeres poderosas en el mundo rural catalán, las feminae, asimiladas por el derecho civil catalán y su original institución del hereu en las que en época moderna y contemporánea serán llamadas las pubilles, las herederas de las antiquísimas feminae, después dominae y ya, en los siglos XIV-XV, dominae et proprietariae. Evidentemente, son cuestiones abiertas que dejo a la consideración de posteriores estudios que vengan a matizar, ampliar y mejorar lo aquí apuntado. Me he sumergido en los recovecos del amor cortés enlazándolo con la herejía cátara y en el rol que jugaron las Buenas Mujeres en la nueva religiosidad, hasta la muerte. Tal vez se puede objetar el no haber tratado en este epígrafe otros movimientos religiosos de la época, no necesariamente heréticos, los cuales subrayaron también la igualdad entre los sexos y la capacidad de mediación femenina, como las beguinas ${ }^{81}$; $u$ otros indicadores fundamentales de la situación de las mujeres que tampoco he tenido en consideración: el monacato ${ }^{82}$ y la santidad. No era mi intención desarrollar todos y cada uno de los aspectos, ni realizar un estudio exhaustivo, imposible por razones obvias de economía de espacio. He abordado las tres imágenes medievales de la mujer: Eva, María y Magdalena, vinculando la exaltación y difusión

81 Elena Botinas, Julia CABaleiro, $\mathrm{M}^{\mathrm{a}}$ dels Àngels Durán, Les beguines: la raó il.luminada per amor, Publicacions de l'Abadía de Montserrat, Barcelona, 2002; Marie-Dominique Chenv, "El despertar evangélico", en Lester K. LitTle y Barbara H. Rosenwein (eds.), La Edad Media a debate, Akal, Madrid, 2003, p. 478-505; Herbert Grundmann, Movimenti religiosi nel Medioevo. Ricerche sui nessi storici tra l'eresia, gli Ordini Mendicanti e il movimento religioso femminile nel XII e XIII secolo e sui presupposti storici della mistica tedesca, Mulino, Bologna, 1980; Beverly Mayne Kienzle y Pamela J. Walker, (eds.), Women Preachers and Prophets through Two Millennia of Christianity, University of California Press, Berkeley-Los Angeles-London, 1998; Ernest McDonnell, The Beguines and Beghards in Medieval Culture with Special Emphasis on the Belgian Scene, Octagon Books, New York, 1969; Carol Neel, "The Origins of the Beguines", en Bennet, Sisters and Workers, cit. nota 6, p. 240-259. Para la relación entre ellas cfr. María-Milagros Rivera GARRETAS, "Las beguinas y beatas, las trovadoras y las cátaras: el sentido libre del ser mujer", en Isabel Morant (dir.), Historia de las mujeres en España y América Latina, t. I, De la Prehistoria a la Edad Media, Cátedra, Madrid, 2005, p. 745-767.

82 La incidencia de las monjas en el sistema y la mentalidad feudal sexuada en Montserrat CABRÉ I PAIRET, "La dedicación de las mujeres a la vida religiosa y el desarrollo del sistema de géneros feudal en los condados catalanes, siglos IX-XI", Arenal. Revista de Historia de las Mujeres 1, 1994, p. 185-208. Para Francia, cfr. Micheline de FonTETTE, Les religieuses à l'âge classique du droit canon. Recherches sur les structures juridiques des branches féminines des ordres, Librairie philosophique J. Vrin, París, 1967; Penelope D. Johnson, Equal in Monastic Profession. Religious Women in Medieval France, The University of Chicago Press, Chicago \& London, 1991; Marthe Moreau, L'age d'or des religieuses. Monastères féminins du Languedoc méditerranéen au Moyen Age, Les Presses du Languedoc, Montpellier, 1988; Michel PARISSE (ed.), Les religieuses en France au XIIIe siècle, Table Ronde organisée par 1'Institut d'Etudes Médiévales de 1'Université de Nancy II et le C.E.R.C.O.M. (2526 juin 1983), Presses universitaires, Nancy, 1989. 
del culto mariano con la sacramentalización del matrimonio. He sugerido, al acabar, la ambigüedad de las posturas, materializada en el secular debate que llevó por título la Querella de las mujeres ${ }^{83}$. Todos estos elementos, junto a otros de notable importancia, como la intensificación misógina ${ }^{84}$ en el siglo XIII, consecuencia de la llamada "revo-

83 Rosa M M CAPEL y Margarita OrTegA, "Textos para la historia de las mujeres en la edad moderna", en Ana Aguado (ed.), Textos para la historia de las mujeres en España, Cátedra, Madrid, 1994, p. 225-315; Robert Archer, Misoginia y defensa de las mujeres. Antología de textos medievales, Cátedra, Madrid 2001; Nieves BARANDA LETURIO, "Las escritoras españolas en el siglo XVI: la ausencia de una tradición literaria propia", en Lucía Montejo Gurruchaga y Nieves Baranda Leturio (coords.), Las mujeres escritoras en la historia de la literatura española, UNED, Madrid, 2002, p, 33-54; Giovanni Boccaccio (c. 1343) / (c. 1380), Elegía de Doña Fiameta / Corbacho, (edición de Pilar Gómez Bedate, Barcelona, 1989); Teresa de Cartagena, Admiraçión Operum Dey (Arboleda de los enfermos/Admiraçión Operum Dey, edición de Lewis Joseph HuTton, Madrid, 1967); Anna Caballé, Una breve historia de la misoginia. Antología y crítica, Lumen, Barcelona, 2000; M M $^{\mathrm{a}}$ Teresa CACHO, "Los moldes de Pygmalión. Sobre los tratados de educación femenina en el siglo de oro", en Miriam Díaz- Diocaretz y Iris Ma Zavala, (coords.), Breve historia feminista de la literatura española en lengua castellana, Anthropos, Madrid, 1993, Vol. I, p. 177-215; Martín DE CóRdoBA, (1499), El jardín de las nobles doncellas, (Prosistas castellanos del siglo XV, edición de Fernando RuBio, Madrid, 1964, Vol. II); Juan DEL Encina, Juan de Enzina contra los que dizen mal de las mugeres, LXIV (Obras completas, Edición, introducción y notas de Ana María RAMBALdo, Madrid, 1978, Vol. III, pp. 1-7); Consuelo Flecha García, "Las mujeres en la historia de la educación medieval", en Graña Cid, cit. nota 57, p. 51-64; Joan Fuster, "Jaime Roig y sor Isabel de Villena” en Revista Valenciana de Filosofia, LVIII, 1995, p. 227-260; Jesús Gómez, El diálogo en el Renacimiento, Cátedra, Madrid, 1988; César Hernández Alonso, Obras completas de Juan Rodríguez del Padrón, Editora Nacional, Madrid, 1982; Josemi LoRENzo ArRIBAS, "Un feminista sereno y misógino progresista en Castilla (1474-1583) Des/autorización de las mujeres en la tradición agustiniana", en Ana Isabel Cerrada Jiménez y Cristina Segura Graiño, (eds.), Las mujeres y el poder. Representaciones y prácticas de vida, Almudayna, Madrid, 2000, p. 147-160; Alvaro DE LuNA, Libro de las virtuosas é claras mujeres (Estudio preliminar de Marcelino Menéndez y Pelayo, Madrid, 1891); Martínez de Toledo, Arcipreste de Talavera o Corbacho, (edición de Michael Gerl, Madrid, 1992); Fray Iñigo de Mendoza, Coplas de Viti Christi, 24 (edizione di Marco Massoli, Firenze, 1997); Hernán MexíA, Otras suyas en que descubre los defectos de las condiciones de las mugeres, por mandado de dos damas; y endereça a ellas estas dos primeras, (Cancionero castellano del siglo XV, edición ordenada por R. FoulchÉ-Delbosc, Bailley-Bailliere, Madrid, Vol. I, 1915, p. 281-285; Ambrosio DE Montesino, Doctrina y reprehensión de algunas mujeres (Cancionero de Fr. Ambrosio de Montesino, edición de Julio Rodríguez Puertolas, Cuenca, 1987); Isabel Morant, "Hombres y mujeres en el discurso de los moralistas. Funciones y relaciones", en Isabel Morant (dir.), Historia de las, cit. nota 80, II, p. 27-61; Diego DE SAN PEdro (1483-1492), Cárcel de amor (edición de Enrique Moreno BÁez, Madrid, 1974); María del Pilar Rabadé Obradó, "Ética y política: Recomendaciones de Fr. Martín de Córdoba a la futura Isabel I", en Ma Victoria LóPEz-CoRdón y Gloria FrANCo (coord.), La reina Isabel y las reinas de España, VIII Reunión científica de la Fundación Española de Historia Moderna, Madrid, 2005, p. 63-76; Juan Rodríguez de la CÁmara o del PAdrón (1438-1445), Triunfo de las donas, (Obras completas, edición de Cesar Hernández Alonso, Madrid, 1982); Francisco de Rojas (1500), Tragicomedia de Calisto y Melibea (La celestina, Alicante, 1982, Vol. II); Cristina SEgura Graiño, "Las mujeres en La Celestina", en Cristina Segura Graiño (coord.), Feminismo y misoginia en la literatura española. Fuentes literarias para la historia de las mujeres, Narcea, Madrid, 2001, p. 47-79; Diego DE VALERA (1441), Tratado en defenssa de virtuossas mugeres, (Prosistas castellanos del siglo XV, edición de Mario PenNA, Madrid, 1958, Vol. I); Enrique de Villena (c.1417), Los doze trabajos de Hércules (edición de Margherita Morreale, Madrid, 1958); Isabel de Villena (1497), Vita Christi (Protagonistes femenines a la Vita Christi, edició a càrrec de Rosanna Cantavella i Lluisa Parra, Barcelona, 1987).

84 Sobre la situación de la mujer en la Edad Media y el problema de la misoginia para el contexto concreto que se ha tratado, $c f r$. Kari Elizabeth BøRRESEN, Subordination et equivalence: nature et role de la femme d'après Augustin et Thomas d'Aquin, Maison Mame, París, 1968; Caroline W. Bynum, Jesus as Mother. 
lución aristotélica", cuando desde las universidades se impuso la lectura obligatoria de las obras de Aristóteles, instaurando la teoría de la polaridad entre los sexos, la cual defiende que los hombres y las mujeres somos sustancialmente diferentes, siendo los hombres superiores a las mujeres ${ }^{85}$, habrán de recibir su tratamiento en profundidad en análisis posteriores. Soy consciente de que mis reflexiones no ofrecen un resultado cerrado ni concluyente, en cierta manera así lo pretendo, dado que las temáticas que he abordado son amplias y están siendo objeto de múltiples revisiones. Mi intención ha sido la de colaborar en esos debates, introduciendo elementos de discusión, siempre susceptibles de matización, ampliación y mejora.

Fecha de recepción: 30 de agosto de 2014

Fecha de aceptación: 11 de enero de 2015

Studies in the Spirituality of the High Middle Ages, California University Press, BerkeleyLos Angeles-London, 1982; Victoria CirLot y Blanca GARí, La mirada interior. Escritoras místicas y visionarias en la Edad Media, Ediciones Martínez Roca, Barcelona, 1999'1 ; Mary Erler, Maryanne Kowalweski (eds.), Women and Power in the Middle Ages, University of Georgia Press, Athens \& London, 1988; Clara Maria Henning, "Cannon Law and the Battle of the Sexes", en Rosemary Ruether (ed.), Religion and Sexism: Images of Women in the Jewish and Christian Traditions, Simon \& Schuster, New York, 1974, p. 267-291; Gerda Lerner, The Creation of Feminist Consciousness. From the Middle Ages to EighteenSeventy, Oxford University Press, New York \& Oxford, 1993; Marirì Martinengo, Claudia Poggi, Marina SAntini, Luciana Tavernini y Laura Minguzzi, Libres para ser. Mujeres creadoras de cultura en la Europa medieval, Narcea, Madrid, 2000; Eleanor McLaughLin, "Equality of Souls, Inequality of Sexes: Woman in Medieval Theology", en Ruether, Religion and Sexism, cit. p. 213-266; Jo Ann McNamara, "De Quibusdam mulieribus: Reading Women's History from Hostile Sources", en Joel T. Rosenthal (ed.), Medieval Women and the Sources of Medieval History, University of Georgia Press, Athens \& London, 1990, p. 237-258; Elizabeth A. Petroff, Body \& Soul. Essays on Medieval Women and Mysticism, Oxford University Press, New York \& Oxford, 1994; Ana Rodríguez López, La estirpe de Leonor de Aquitania. Mujeres y poder en los siglos XII y XIII, Crítica, Barcelona, 2014; Josep-Ignasi SARANYANA, La discusión medieval sobre la condición femenina (siglos VIII al XIII), Publicaciones Universidad Pontificia de Salamanca, Salamanca, 1997.

85 Rivera Garretas, La diferencia sexual, cit. nota 4, p. 98-99. 